\title{
본ㄴ
}

ISSN: $2340-8685$

Investigaciones Sobre Lectura

\section{Reading in English as a Foreign language: Examining differences in reading speed, comprehension, efficacy and $L 1$ cross-linguistic influence across grades}

Àngels Llanes Baró
Universidad de Lleida

Recibido: Mayo 2018

Aceptado: Julio 2018

\begin{abstract}
Reading in a second or foreign language (L2) is a more complicated process than reading in one's first language because it requires additional demands on the reader. Reading can be assessed from various domains. Reading fluency is known to be the most determining domain to identify reading problems (Rasinski, 2000). However, the goal of reading is comprehending a text, so comprehension should not be disregarded either. Despite the importance of reading in an L2, few studies have focused on examining its effects. The goal of the present study is threefold: first, to provide the estimates of L2 English reading rates of L1 Catalan/Spanish students of different ages and grades; second, to examine whether there are significant differences between participants of different grades in terms of reading rates, comprehension and efficacy; and third, to explore whether the students' reading rates in the L1 are correlated with their $\mathrm{L} 2$ reading rates and if so, the extent to which $\mathrm{L} 1$ reading rates explain $\mathrm{L} 2$ reading rates.

790 Catalan/Spanish learners of English participated in the present study. Participants were from 5 th grade primary (age 12) to 2 nd baccalaureate (age 18). They were asked to read two texts, one in English and the other one in their L1 (they could choose between Catalan or Spanish). They were asked to answer 7 multiple-choice comprehension questions after reading each text. Next, their scores on fluency (words read per minute), comprehension (percentage of comprehended text) and efficacy (a formula that integrates speed and comprehension) were obtained. Results show that reading fluency and comprehension are not linear and that they do not necessarily improve over time. Results also show that L1 and L2 reading fluency rates are highly correlated and that L1 reading rates explain a large percentage of $\mathrm{L} 2$ reading rates.
\end{abstract}

Keywords: L2 reading rates, L1 reading rates, Reading in a foreign language, Grade, L2 reading comprehension

Llanes, A. (2018). Reading in English as a Foreign language: Examining differences in reading speed, comprehension, efficacy and L1 cross-linguistic influence across grades. Investigaciones Sobre Lectura, 9, 1-49. 


\section{Introduction}

Reading is possibly one of the most important skills as it is essential to function in today's society: it gives access to information and knowledge. Reading is a complex activity that involves, broadly speaking, two processing levels. The lower level processing components have to do with word recognition and are concerned with letter identification, the grapheme-phoneme correspondence, and the association of words with their meaning. The higher level processing components have to do with syntax and the integration of textual information, and includes processes such as resolving ambiguities in the text, connecting words with their referents, and integration of ideas with the reader's general knowledge (Nassaji, 2003; Segalowitz, Poulsen \& Komoda, 1991).

Reading can be assessed from various domains, reading speed being one of them, probably the most determining one when it comes to identifying reading problems. As Rasinski (2000) claims, reading speed is crucial to identify inefficient reading, even when comprehension is satisfactory. Although comprehending a text is the goal of reading, reading rate should not be disregarded because it is evidence of text processing: an inefficient reader will invest much more time in reading the same text than an efficient reader (assuming that comprehension is adequate), and this might lead to greater frustration and demotivation to read and, consequently, to less frequent reading activity (Gómez-Domínguez, 2016; Jainta and Kapoula, 2011; Stanovich, 1986).

Reading in a second or foreign language (L2) is even a more complicated process because it requires additional demands on the reader (Wurr, 2003), so slow reading can affect, among other things, the compulsory reading for students of a specific course, especially at university levels. Raymond and Parks (2002, p. 161) found that L2 students "read $50 \%$ or less in their MBA textbooks on a regular basis because they had too much to read, read very slowly, and thus lacked the necessary time to read". Despite the importance of reading in an L2, few studies have focused on examining its effects.

The goal of the present study is threefold: first, to provide the estimates of L2 English reading rates of L1 Catalan/Spanish students of different ages and grades; second, to examine whether there are significant differences between participants of different grades in terms of reading rates, comprehension and efficacy; and third, to explore whether the students' reading rates in the L1 are correlated with their L2 reading rates and if so, the extent to which L1 reading rates explain L2 reading rates.

\section{Literature review}

There is little research on L2 reading skills, and the scant research that examined L2 rates revolves mostly around two lines: a) L2 reading rates as a result of an L2 reading programme (mostly with college students), and b) L2 word recognition or decoding as a result of specific sub-skills involved in L1 reading, such as working memory or phonological awareness. Whereas the former usually reports on the words per minute read before and after a specific reading programme (using connected texts), the latter usually reports on the ability to recognise single words or syllables considering the participants' L1 influence. 
Most of the literature on L2 reading has focused on the effects that a specific reading programme has on L2 development. Such programmes include extensive reading, reading-while-listening, reading only, repeated reading and timed reading. In either case, previous research has shown that all these approaches or instructional techniques to L2 learning have positive effects on several domains such as reading rates (Chang, 2012; Iwahori, 2008; Taguchi et al., 2004), vocabulary (Webb \& Chang, 2012; Webb \& Chang, 2014) and comprehension (Beglar, Hunt, \& Kite, 2012; Nuttall, 2005).

There is little research that focuses on L2 reading rates, and most of this research has focused on the L2 reading rates development of university students (Beglar et al., 2012; Huffman, 2014; McLean \& Rouault, 2017; Rob \& Susser, 1989). Only six studies are known to have investigated the L2 reading rates development of teenagers, and five do so in an extensive reading treatment (see Appendix A for a review of the studies that explored L2 reading rate). One of the first studies to examine the L2 reading development with a cohort of teenagers was Lai (1993). Namely, the author explored the effects of a summer extensive reading course on L2 reading comprehension and speed with a group of 266 L1-Chinese learners of English from grades 7-9 (aged 11-15). The author found that in general, participants significantly improved comprehension and reading speed (with a mean score of 85 words read per minute (WPM) in the pretest to a mean of $181 \mathrm{WPM}$ in the post-test). Another scholar who documented the effects of L2 extensive reading on L2 reading rates and comprehension with teenagers is Sheu (2003). The author compared two groups of L1-Chinese L2-English adolescents aged 13-14, one reading graded readers and the other one books written for English native-speaker children, with a control group who followed a traditional approach. In terms of reading speed, Sheu found that participants in the three groups significantly improved from the pre-test to the post-test, but that participants in the experimental groups showed greater improvement in reading rates and comprehension than participants in the control group, with rates ranging from 59 WPM in the pre-test to 95 WPM in the post-test for the graded readers group and 98 WPM in the pre-test to 136 WPM in the post-test for the participants reading books for English native-speaker children. More positive evidence of the effects of an extensive reading programme with teenagers comes from Iwahori (2008). Participants in Iwahori's study, who were 33 L1Japanese L2-English high school students aged 16-17, were provided with graded readers, which were read over seven weeks. Participants improved their reading speed from 84 WPM in the pre-test to 112 WPM in the post-test, an improvement that turned out to be significant. Likewise, Matsui and Noro (2010) also investigated the effects of extensive reading on reading fluency with teenagers. The authors compared the reading fluency over a school year of two groups of L1-Japanese L2-English high school students, one following an extensive reading approach that involved 10 minutes of reading at the beginning of the class $(n=60)$, and the other one followed an approach that did not involve reading extensively $(n=62)$. The authors found that the extensive reading group significantly improved their fluency, whereas the control group did not, and the difference between groups was also significant. Namely, the experimental group read at a speed of 88.57 WPM in the pre-test and of 108.32 WPM in the post-test, 
whereas the control group participants read at a mean of 89.29 WPM in the pre-test and of 94.79 WPM in the post-test. Similarly, He (2014) investigated the relationship between extensive reading and reading speed. The author compared the reading rate gains made by two groups $(\mathrm{n}=33$ each) of L1-Chinese high school learners of English (L2), one that was involved in extensive reading and was not told about the amount and level they should read (free reading), and the other one that also involved in extensive reading, but the students were told how much they were expected to read (integration reading). Both groups of participants increased their reading rates, but participants in the integration reading programme showed a greater increase than participants in the free reading programme; namely the former had a reading speed of 139 WPM in the pre-test and of $210 \mathrm{WPM}$ in the post-test, whereas the latter experienced a reading rate of 145 WPM in the pre-test and of 212 WPM in the post-test. One last study that reports on the L2 reading rates and comprehension of high school students is Fujita and Yamashita (2014). However, these authors did not report on the effects of a specific reading programme, they provide a cross-sectional study with the relation between L2 reading rates and comprehension of 125 Japanese high school students learners of English. The authors found that reading rate and comprehension in an L2 were significantly correlated, although the relation was weak.

Thus, the studies mentioned so far show that L2 reading rates are variable: He's (2014) and Fujita \& Yamashita's (2014) participants are of comparable ages, but their reading rates are quite divergent (the former reports rates of approximately 135 WPM and the latter rates of 93 WPM). Furthermore, most studies that examine the L2 reading rate have been conducted with adults and mostly from Asia (see Appendix A); only six studies document the L2 reading rates of adolescents, and none of children. Hence, one of the goals of the present study is to fill this gap by providing the estimates of L2 reading rates, comprehension and efficacy of L1 Catalan/Spanish learners of English as an L2 of different ages (10-18). Although there are several accepted reading fluency scales for students reading in an L1 (Bisquerra, 1994; Hasbrouck \& Tindal, 2006; Morris, 2008), there is no such scale, to my knowledge, for students reading in a foreign language (L2). Once tentative L2 reading rates are established, another aim of the present study is to examine whether there are significant differences between participants of different ages and grades.

\section{L2-word recognition as a result of specific sub-skills involved in L1 reading}

The cross-linguistic influence in reading has long been acknowledged by several scholars (Durgunoglu, 2002; Lallier et al., 2016; Nassaji, 2014). It is known that reading in an L2 is more complicated than reading in an L1 because when L2 learners start learning the L2, they already master or have a reasonable good command of their L1 (except for bilingual children and other particular types of learners); therefore, they already have a large vocabulary and a good control of the L1. Additionally, it is common to start learning how to read in an L2 when the L2 learners are still in their initial stages of the L2 learning, so when their proficiency level is still low. The influence of the participants' first language (L1) reading skills on their L2 reading skills has been identified to occur in different domains, such as phonological awareness, syntactic awareness, word-decoding, and orthography among other areas (Grabe, 2009).

Phonological awareness (PA) consists of identifying and manipulating a word's morphological constituents. Studies focusing on the cross-linguistic transfer of PA suggest that PA is related to word recognition and spelling (Adams, 1990). Moreover, a 
study conducted by Bialystok et al. (2005) examined the PA and word decoding of three groups of 5/6-year-old participants, an English monolingual group, a Chinese monolingual group, and an English/Chinese bilingual group who were starting to learn how to read in English (L2). The authors found that PA was related to language exposure and instruction, and that it transferred across languages for both bilinguals and L2 learners.

Regarding decoding, studies such as Durgunoglu et al. (1993) examined the factors affecting English word identification performance of Spanish beginner learners of English (L2). The participants' letter naming, phonemic awareness in Spanish, word recognition in English and Spanish, and proficiency level in English and Spanish were tested. The results showed that phonemic awareness and Spanish word recognition affected their English word and pseudo-word recognition capacity. In the same vein, Da Fontoura and Siegel (1995) examined the nature of language, memory and reading skills of a group of English heritage speakers of Portuguese aged 9-12. The authors found that decoding transferred between languages in that children who had low reading scores in English also had low reading scores in Portuguese. However, these authors found that in terms of syntactic awareness, the skilled readers only differed from their monolingual English counterparts in that the bilingual readers had significantly lower scores on the English syntactic awareness task. Syntactic awareness was also examined by Abu-Rabia (1995). Participants were 143 Arab children aged 8-11 and they were administered several tests measuring working memory, visual, oral close, phonological, word recognition, spelling, orthographic, and word attack tests. The authors found that the word recognition test was significantly correlated with phonological skills, semantic processing, syntactic knowledge and working memory. Unskilled readers showed a significant delay in these skills, especially at the phonological and semantic levels.

Finally, in terms of working memory (WM), several studies showed that cognitive factors such as WM play an important role (Alptekin \& Erçetin, 2009; Joh \& Plakans, 2017). One of such studies is Gholamain and Geva (1999), who investigated the effects of cognitive factors such as English (L1) WM, Persian (L2) WM, English and Persian letter-naming speed, and Persian oral proficiency level on English and Persian word recognition and English and Persian pseudowords decoding. The authors found that basic cognitive skills were correlated between languages and that the same cognitive variables were significant predictors of English and Persian word recognition, and English and Persian pseudoword decoding.

The large number of studies examining discrete elements such as PA and WM involved in reading contrasts with the relatively few studies focusing on the crosslinguistic influence of a skill such as silent reading rate (reading connected text), and very few, if any, on examining the silent reading fluency in an L2 including school-aged children. Since this type of population is still developing their L1 reading skills, this should provide understanding of the cross-linguistic relationships in reading fluency.

Llanes, A. (2018). Reading in English as a Foreign language: Examining differences in reading speed, comprehension, efficacy and L1 cross-linguistic influence across grades. Investigaciones Sobre Lectura, 9, $1-49$. 


\section{Method}

The present paper tries to fill the gaps in the L2 reading area by answering the following research questions:

1. What are the silent reading rates in English (L2) of L1-Spanish/Catalan students of different grades?

2. Are there significant differences between participants of different grades in reading rates, comprehension and efficacy?

3. Are reading rates in the $\mathrm{L} 1$ related to reading rates in the $\mathrm{L} 2$ ?

3.1 If so, what percentage do' grade' and 'L1 rates' explain of L2 reading rates?

\section{Participants}

790 students $(\mathrm{n}=393$ males, $\mathrm{n}=397$ female) from grades 5 (primary) to preuniversity students participated in the present study. Students are Catalan/Spanish bilinguals aged 10-18, who study English as an L2. Participants with a learning disorder such as dyslexia or with a low level of Catalan or Spanish were excluded from the study. Data from the primary students $(n=157)$ (Grades 5 and 6) come from 3 different schools in Catalonia (see Table 1 below to see the schools' characteristics), whereas the remaining participants $(n=633)$ come from 4 high schools $(81$ participants from grade 5, 76 participants from grade 6, 168 participants from grade 7, 128 participants from grade 8,135 participants from grade 9,125 participants from grade 10, 42 participants from grade 11, and 35 participants from grade 12). Data from students in schools or high schools of different characteristics (rural vs. urban or public vs. semi-private) were included. The participants from all the schools and high schools that participated in the present study belonged to the middle class and they were all informed that they participated in a research project. However, they were not informed of the focus of the study so that the results were more reliable. 
Table 1. Schools' characteristics

\begin{tabular}{|c|c|c|c|c|}
\hline School & Grades & School type & n students (grade) & Total sts \\
\hline \multirow[t]{2}{*}{ VS } & $5-6$ & Public \& rural & $\mathrm{n}=25(5)$ & $n=40$ \\
\hline & & & $\mathrm{n}=15(6)$ & \\
\hline \multirow[t]{6}{*}{ EC } & $5-10$ & Semi-private \& urban & $\mathrm{n}=36(5)$ & $\mathrm{n}=211$ \\
\hline & & & $\mathrm{n}=38(6)$ & \\
\hline & & & $\mathrm{n}=40(7)$ & \\
\hline & & & $n=46(8)$ & \\
\hline & & & $\mathrm{n}=27(9)$ & \\
\hline & & & $\mathrm{n}=24(10)$ & \\
\hline \multirow[t]{6}{*}{ MM } & $5-10$ & Semi-private \& rural & $\mathrm{n}=20(5)$ & $\mathrm{n}=186$ \\
\hline & & & $n=23(6)$ & \\
\hline & & & $n=41(7)$ & \\
\hline & & & $\mathrm{n}=30(8)$ & \\
\hline & & & $\mathrm{n}=39(9)$ & \\
\hline & & & $\mathrm{n}=33(10)$ & \\
\hline \multirow[t]{6}{*}{$\mathbf{L P U}$} & $7-12$ & Public \& rural & $\mathrm{n}=87(7)$ & $\mathrm{n}=353$ \\
\hline & & & $\mathrm{n}=52(8)$ & \\
\hline & & & $\mathrm{n}=69(9)$ & \\
\hline & & & $\mathrm{n}=68(10)$ & \\
\hline & & & $\mathrm{n}=42(11)$ & \\
\hline & & & $\mathrm{n}=35(12)$ & \\
\hline
\end{tabular}

\section{Instrument and procedure}

In order to collect the data, participants were asked to read a text in their L1 (Catalan or Spanish) and one in English (L2). The L1 text was a narrative passage from a book written for students aged 10 onwards. This book was published both in Catalan and Spanish and the translation was done by the author herself. The text in Catalan contained 192 words and the Spanish text comprised 185 words (see Appendix B). 
The English text was a narrative passage that was taken from a book that belonged to the A1 level and comprised 220 words. This level was chosen because previous research shows that one requirement to measure reading rates is text suitability, in which the text has to be well within the students' capability (Carver, 1990; Huffman, 2014). Its Flesh-Kincaid readability index was 91.7, which indicates that it is very easy to read and not difficult for the youngest participants. Both texts were computer administered. After reading each text, participants were asked to answer seven general comprehension questions. The texts and questions were previously piloted and a few small changes were made (for example in the L1 texts there was the word peseta, which was changed to moneda). In order to counterbalance task effects, half of the participants in each grade were asked to start reading the text in te L1 and the other half started reading the text in the L2. The same texts were used for all the participants because previous research has acknowledged the need of comparing "groups with differing amounts of time studying the L2 using the same test" (Chuang et al., 2014, p. 113).

Participants were taken to the computer lab and they were given the webpage where the instrument was found. The test was individual (there was one computer per student) and students were asked to read the texts silently and at their normal pace. The researcher emphasized the need to be concentrated and to start reading as soon as the text appeared. Students were also informed that after reading each text they would have to answer several comprehension questions. Participants first selected the text (Catalan/Spanish or English) they wanted to read. When they clicked on the 'Start' button, the text appeared and the chronometer started, although they could not see it and they were not told what the focus of our research was so that the results were not influenced. When they finished reading the text they clicked on the 'Finish' button (and then the chronometer stopped) and the comprehension questions appeared automatically. These questions were in the students' L1 even for the English text to make sure that if they answered incorrectly, it was not because they did not understand the questions. Once they saw the comprehension questions, it was not possible for the students to go back and check the text again. The comprehension questions consisted of seven multiple-choice questions with four possible answers and only one correct option. After answering the comprehension questions and saving the answers, the following measures were obtained.

\section{Measures}

Four measures were obtained. The first one was words per minute (WPM), which was calculated automatically taking into account the text length and the total time taken to read it. Two measures of comprehension were included: the raw score of the correctly answered questions (out of seven), and the percentage of comprehension, which was calculated through the formula: number of correct answers*100/7. The last measure was reading Efficacy, which is a formula that involves both speed and comprehension ([WPM x \% comprehension]/ 100) (Álvarez, 1993; López \& Sabé, 2008). For Efficacy, the maximum score the students were able to obtain was equal to their WPM score, but this was only for the maximum score, as students were penalized for any comprehension mistake they made and so the Efficacy scores can never be higher than the WPM scores; for example, a participant scoring 85 WPM would get a 85 score for Efficacy assuming s/he answered all the comprehension questions correctly. 
Research question 1, which attempted to establish silent L2 reading rates for participants in each grade, was addressed by inspecting the descriptive statistics for the 8 different grades. The mean and standard deviation of WPM, Comprehension (percentage) and Efficacy were calculated for participants in each grade and can be seen in Table 2.

Table 2. Descriptive statistics for each of the measures in English

\begin{tabular}{lllll}
\hline Grade & Age & WPM & comprehension (\%) & Efficacy \\
5 & $10-11$ & $65.06(24.64)$ & $82.14(18.3)$ & $52.12(25.5)$ \\
6 & $11-12$ & $74.71(20.37)$ & $82.38(17.98)$ & $59.24(21.16)$ \\
7 & $12-13$ & $75.79(32.02)$ & $83.57(16.38)$ & $62.62(29.16)$ \\
8 & $13-14$ & $77.46(29.79)$ & $83.04(17.82)$ & $64.55(30.79)$ \\
9 & $14-15$ & $76.81(26.51)$ & $89.04(13.84)$ & $67.85(25.74)$ \\
10 & $15-16$ & $64.35(18.9)$ & $90.46(14.3)$ & $57.96(20)$ \\
11 & $16-17$ & $71.85(31.7)$ & $90.01(14.7)$ & $64.79(32.1)$ \\
12 & $17-18$ & $65.66(21.39)$ & $97(6)$ & $63.46(20.89)$ \\
& & & & \\
\hline
\end{tabular}

In order to answer research question 2, which asked whether there were significant differences between grades, three different one-way ANOVAs were run, each with grade as the independent variable but with different dependent variables: WPM, Comprehension (percentage) and Efficacy, respectively. The ANOVA run with WPM as the dependent variable indicates that there was a significant effect for grade $(F(7,800)=3855), p=.006)$. Post-hoc comparisons using the Tukey HSD test indicated that, the mean score for grades 7,8 and 9 were significantly higher than that of grade 10 , and these differences showed medium effect sizes as Cohen's (d) were 0.43 (grades $7-10$ ), 0.52 (grades 8-10) and 0.54 (grades 9-10). The ANOVA with comprehension as the dependent variable also indicated a significant effect for groups $(F(7,800)=10073$, $\mathrm{p}=.000$ ), and the post-hoc comparisons through the Tukey HSD test showed that the means of grade 5 were significantly lower than those of grades $9,10,11$ and 12, that means of grade 6 were also significantly lower than those of grades $9,10,11$ and 12, 
that those of grade 7 were significantly lower than those of 10, 11 and 12, and that those of grade 8 were also significantly lower than those of grades 9, 10, 11 and 12. As Table 3 below shows, these differences are medium except for the difference between grade 12 and the remaining grades, which is large. Finally, the ANOVA conducted with Efficacy as the dependent variable also turned out to be statistically significant (F ( 7 , $800)=2885, \mathrm{p}=.006)$. The post-hoc analyses indicated that the mean score for grade 5 was significantly lower than those of grades 9 and 11 . However, the difference in mean scores for Efficacy in English was small $(d=0.25$ for grades 5-9 and $d=0.12$ for grades $5-11)$.

Table 3. Cohen's d effect sizes for English comprehension

\begin{tabular}{lllll}
\hline Grades & $\mathbf{9}$ & $\mathbf{1 0}$ & $\mathbf{1 1}$ & $\mathbf{1 2}$ \\
$\mathbf{5}$ & 0.42 & 0.50 & 0.47 & 1.09 \\
$\mathbf{6}$ & 0.41 & 0.49 & 0.46 & 1.09 \\
$\mathbf{7}$ & - & 0.44 & 0.41 & 1.09 \\
$\mathbf{8}$ & 0.37 & 0.45 & 0.42 & 1.04
\end{tabular}

Finally, in order to answer RQ3, which asked whether reading rates in the L2 were related to reading rates in the L1, bivariate correlations between WPM in the L2 and in the L1 were conducted for students in each grade. As shown in Table 4 below, L2 and L1 reading rates were always significantly correlated, and this correlation was strong for grades 5 and 12, weak for grade 11, and moderate for the remaining grades.

Table 4. Correlations between WPM in the L2 and L1 for each grade

\begin{tabular}{l|llllllll}
\hline Grade & 5 & 6 & 7 & 8 & 9 & 10 & 11 & 12 \\
& & & & & & & & \\
& & & & & & & & \\
\hline Correlation & $.476^{* * *}$ & $.501^{* *}$ & $.576^{* *}$ & $.687^{* *}$ & $.597^{* *}$ & $.581^{* *}$ & $.374^{*}$ & $.832^{* *}$ \\
$\mathbf{p}$ & .000 & .000 & .000 & .000 & .000 & .000 & .015 & .000 \\
$\mathbf{n}$ & 86 & 76 & 184 & 128 & 135 & 124 & 42 & 34
\end{tabular}

In order to answer sub-question 3.1, which asked about the percentage of the L2 reading rates explained by Grade and L1 rates, a linear regression analysis was run. It was found that Grade only accounted for $6 \%$ of the model, whereas L1 rates explained $61.9 \%$ of L2 rates (see Appendix C).

Next, a series of linear regression analyses were performed for each grade, with reading rates in the L2 as the dependent variable and L1 rate as the independent variable. It was found that in all the grades L1 reading rates accounted for a high percentage of L2 reading rates, with values ranging from $37.4 \%$ in grade 11 to $89.2 \%$ in grade 12 (see Appendix $\mathrm{C}$ for more detailed results). 


\section{Discussion and conclusion}

The first research question attempted to establish silent reading rates in English (L2) for participants of different grades. In the absence of research on L2 reading fluency with primary school students reading connected text in an L2, the reading speed of participants in grades 5 and 6 could not be compared to any previous study. However, the reading speed of students in grades 7-9 is comparable, although a bit lower, to the speed of Lai's (1993) and Matsui and Noro's (2010) participants. The rates of students in grade 8 are higher than those in Sheu's (2003) study, who also included grade 8 participants and whose reading speed was even lower than the reading speed of grade 5 students in the present study. Previous studies looking at reading speed in an L2 with university students have also reported varying reading speeds. Hirai's (1999) participants, for example, reported speeds that range from 60 to $139 \mathrm{WPM}$, and Beglar et al. (2012) and Iwahori's (2008) participants show similar reading speeds (87-104 WPM and 84-112 WPM, respectively). Nevertheless, other studies with college students have reported lower reading speeds, such as 68 WPM (Bell, 2001), 78 WPM (Robb \& Susser, 1989), and 64 WPM (Taguchi et al., 2004), and these reading speeds of college students are even lower than those of students in grades 5 and 6 of the present study. The present study shows that reading rates in an L2 are very variable and that grade does not necessarily guarantee faster or more efficient L2 reading (in line with McCollum, 2012), but it seems to guarantee better comprehension. This is probably due to the complexity of reading in an L2, which is likely influenced by many aspects such as reading ability in the L1 (see below), knowledge of vocabulary in the L2, the capacity of decoding the text in the L2, and the distance between the L1 and L2 among other things. In this respect, it must be pointed out that practically all the studies examining the effect of a reading programme on L2 reading rates include languages that are very distant (Japanese and Chinese students learning English), whereas the present study includes two languages that are closer to the L2 (Catalan/Spanish and English) and that share the alphabet (although they have a different phoneme-grapheme correspondence).

Research question 2 asked whether there were significant differences between participants of different grades in terms of L2 reading speed, comprehension and Efficacy. Significantly faster reading rates were expected in favour of older participants given that these participants have received more hours of instruction in English and consequently have been exposed to L2 print more than younger participants; moreover, older participants are supposed to have a better command of the lower level processing skills explained above, which include decoding. Notwithstanding, surprisingly very few significant differences between groups were found regarding reading speed, and the few significant differences favoured younger students (the only significant differences were between participants in grade 10, who read significantly more slowly than participants in grades 7, 8 and 9). Descriptive statistics show that participants in grades 10 and 12 read practically at the same speed as participants in grade 5. Data from grades 11 and 12 students must be taken with caution because they were two small groups from a single high school and hence these data cannot be generalized. However, data from grade 10 students come from 125 students in three different high schools, both public and semi- 
private. The fact that grade 10 students read practically at the same speed as grade 5 students and similar to the students in the remaining grades suggests that maybe younger students are better prepared than older students (they might be exposed to extracurricular English such as watching cartoons or playing games more than older participants). This finding suggests that, regardless of their grade and age, students learning English as an L2 in countries like Spain, where exposure to the L2 is practically limited to the classroom (3-4 h per week), will need much time to read with some fluency in the L2 given that the maximum reading rate was 77.46 WPM (students in grade 8). This rate is far from the suggested 200 WPM rate (Anderson, 2008; Carver, 1992). Additionally, if we bear in mind that grade does not guarantee improvement in L2 reading rate, most of these students are doomed to invest much time in reading in the L2; reading is probably the most indispensable skill for university students, so if they ever attend university and are required to read in the L2, this could demotivate them or deprive them from doing other tasks given the amount of time they will have to invest on reading. Since previous research has shown the efficiency of reading programmes (some of Lai's (1993) teenage participants experienced an increase of 96 WPM, which is already higher than any of the speeds shown for the participants in the present study), a focus on reading in the L2 should be implemented in schools in order to improve the reading speed of participants. As for comprehension, this measure yielded most of the significant differences between groups, with older students scoring significantly higher than younger students. A tentative explanation to this finding could be that older participants have a wider vocabulary knowledge and probably higher general proficiency level (they have received instruction in English for more years than younger students) and therefore they understood the text significantly better. Another possible explanation to this finding is that older participants supposedly read better in their L1, so there might have been some positive transfer from the L1 affecting the lower-level processes and consequently they might not have had to focus their attention on the lower-level processes such as decoding and hence they might have been able to concentrate more on comprehension (Nassaji, 2013; Segalowitz, Poulsen \& Komoda, 1991; Taguchi \& Gorsuch, 2002). However, it must be noted that the first significant differences in comprehension did not appear until grade 9 (which was significantly different from grades 5 and 6), suggesting that students in a school or high school following a traditional curriculum with no specific focus on reading need to have received many years of instruction in English before the difference in comprehension is significant.

Finally, regarding reading Efficacy in the L2 it was found that students in grade 5 read less efficiently than those in grades 9 and 11. Both the reading speed and comprehension of students in grade 5 were lower than those in grades 9 and 11. As mentioned above, this could be due to the advantage of older students with the letter identification and the association of the words with their meaning, and also due to the possible higher L2 level or larger lexicon they have after having received more years of instruction and of exposure to the L2. The fact that only two grades ( 9 and 11) differed significantly from grade 5 indicates that the Efficacy (or comprehension-based reading rate) is also similar across grades when there is not a special focus on reading and that years of general English instruction do not guarantee reading (significantly) better.

Thus, it seems that reading speed and Efficacy are not so sensitive as comprehension when it comes to catering for gains in L2 reading. This finding is not unexpected given that the schools included in the present study did not have any specific focus on reading, and like traditional schools in Spain they focus their 
instruction mostly on grammar and vocabulary. Additionally, students usually have reading exams, but they consist of understanding the text as students are usually required to answer a few comprehension questions or summarize what the text says; therefore, students probably allocated more attention to comprehension than to speed as their reading speed (in the L2) has never been tested before.

The third research question asked whether reading rates in the L2 are related to reading rates in the $\mathrm{L} 1$ and what percentage of $\mathrm{L} 2$ reading rates was explained by Grade and L1 rates. It was found that for participants in all grades, the reading rate in the L1 was significantly correlated with their reading rates in the $\mathrm{L} 2$, and that $\mathrm{L} 1$ reading rates explained a large percentage of L2 reading rates for participants in all grades. Learning to read in an L2 is aided by transference of knowledge and skills acquired in L1 reading (Nassaji, 2014). Since "certain literacy concepts and strategies [...] can be universal and operate across languages" (Durgunoglu, 2002, p. 192), "some insights and skills learned in one language need to be learned only once, after which time they can be applied to other languages being learned" (Bourgoin, 2014, p. 358). This finding can be explained by the Automaticity Hypothesis (Laberge \& Samuels, 1974), which posits that the reader needs to perform lower-identification processes of decoding words with the minimum amount of attention possible given that working memory capacity is limited and hence if the reader decreases the amount of time devoted to decoding words he or she will be able to allocate more attention to comprehension. Previous studies confirm that L2 readers rely on their L1 orthographic processing knowledge when processing L2 texts (Hamada \& Koda, 2008; Sun-Alperin \& Wang, 2011). This crosslanguage phonological transfer has been documented with students of various first languages learning English as an L2 (French: Comeau, Cormier, Grandmaison, \& Lacroix, 1999; Italian: D’Angiulli, Siegel, \& Serra, 2001; Korean: Wang, Park, \& Lee, 2006; Spanish: Durgunoglu et al., 1993), and it is in line with previous findings that have found that Spanish phonological processing skills predict English word reading performance (Gottardo, 2002; Lindsey et al., 2003) and spelling (Bryant et al., 1990). Previous findings suggest that this difference between L1 and L2 is clear with students at the beginning and intermediate level, but as the reader's L2 proficiency improves, the processes involved in L1 and L2 reading become more similar. Thus, the fact that in all grades the participants' L1 reading rates were significantly correlated with their L2 reading rates suggests that participants in the present study were not L2 advanced students but rather beginners or students at an intermediate level.

The present study attempted to establish L2 silent reading rates of L2 learners of different grades, to explore whether there were significant differences in terms of speed, comprehension and Efficacy between participants of different grades, and whether the participants' L1 reading speed was correlated to their L2 reading speed and if so, to what extent $\mathrm{L} 1$ reading rates explained $\mathrm{L} 2$ reading rates.

It was found that participants read at a speed that ranges from 65.06 to 77.46 WPM, and that being in a higher grade did not guarantee a faster or more efficient rate in English. Relatedly, there were very few significant differences between grades in terms of speed and Efficacy, and most of them were regarding comprehension, which 
favoured older students. Finally, the participants' L1 reading speed was significantly correlated to their L2 reading speed and their L1 reading speed explained a large percentage of L2 reading speed. If one accepts the 200 WPM rate suggested by renown scholars as a reasonable goal, these findings are rather unpromising because the participants who showed the fastest reading rate read at less than half of this speed (77.46 WPM) when the L2 text was very basic, and more years of instruction in English without a specific focus on reading neither seems to guarantee faster nor more efficient reading. Given that previous research examining the effects of different reading programmes has shown that implementing a specific reading programme such as extensive reading or timed reading leads to a faster reading speed and comprehension, more reading programmes should be implemented in schools to boost the students' L2 reading skills. However, although most research has found significant differences in favour of those students in a specific reading programme, the cost-benefit ratio could be called into question given that implementing a reading programme implies a considerable economical investment (i.e. material and sometimes additional equipment must be acquired) and the result can be variable given that some previous studies have found a dramatic increase of reading rates, but others have experienced just a modest increase.

Finally, since the participants' L1 rates were correlated with their L2 rates and they explained a high percentage of their L2 rates, another pedagogical implication of the present study is that L1 rates should not be disregarded because they not only indicate reading problems in the L1 but also in the L2. Given that this finding suggests that fluency is not language-specific, reading speed should be of paramount importance in the literacy curricula of institutions.

The present study also has a methodological implication, which derives from the finding that reading rates and Efficacy did not show so many significant differences as comprehension. Several previous studies have found that a faster reading rate leads to better comprehension (Iwahori 2008; Macalister, 2010), but some others have not found any relationship between them. The present study seems to point to the direction that when reading in an L2 these measures develop independently and that they are not related to each other. Further research is needed to clarify this, but if it confirms that these are two unrelated measures, teachers and reading programme organizers should take this finding into account. In any case, it would be interesting that L1/L2 reading rates were periodically checked to detect any reading problems before it is too late and students demotivate and consequently stop reading and having access to information or knowledge in the L2.

Acknowledgements

This study was supported by grant FFI2016-80576-P and grant Iberoamérica del Banco Santander para Jóvenes Profesores Investigadores. I would like to thank my colleague Elsa Tragant for her feedback on a previous version of this manuscript, and my colleague Raquel Serrano for her help with the Spanish version. I would like to thank Judith Borràs for her her with the Spanish translation. 


\section{References}

Abu-Rabia, S. (1995). Learning to read in Arabic: Reading, syntactic, orthographic and working memory skills in normally achieving and poor Arabic readers. Reading Psychology, 16 (4), 351-394.

Adams, M. J. (1990). Beginning to read: Thinking and learning about print. Cambridge, MA: MIT Press.

Alptekin, C. \& Erçetin, G. (2009). Assessing the relationship of working memory to L2 reading: Does the nature of comprehension process and reading span task make a difference? System, 37, 4, 627-639.3

Álvarez, C. M. (1993). Técnicas de lectura eficaz. Revista interuniversitaria de formación del profesorado, 18, 83-91.

Anderson, N. J. (2008). Practical English language teaching: Reading. New York: McGraw-Hill.

Beglar, D. \& Hunt, A. (2014). Pleasure reading and reading rate gains. Reading in a foreign language, 26, 29-48.

Beglar, D., Hunt, A., \& Kite, Y. (2012). The effect of pleasure reading on Japanese university EFL learners' reading rates. Language Learning, 62, 665-703.

Bell, T. (2001). Extensive reading: Speed and comprehension. The Reading Matrix, 1.

Bialystok, E., McBride-Chang, C., \& Luk, G. (2005). Bilingualism, language proficiency, and learning to read in two writing systems. Journal of Educational Psychology, 97 (4), 580-590.

Bisquerra, R. (1994). Eficiència lectora. La mesura per al seu desenvolupament. Exercicis i barems. Madrid: Centro de Estudios ADAMS.

Bourgoin, R. (2014). The predictive effects of L1 and L2 early literacy indicators on reading in French immersion. The Canadian Modern Languge Review, 70, 3, 355-380.

Bryant, P. E., MacLean, M., Bradley, L. L., \& Crossland, J. (1990). Rhyme and alliteration, phoneme detection, and learning to read. Developmental Psychology, 26, 429-438.

Carver, R. P. (1990). Reading rate: A review of research and theory. New York: Academic Press.

Carver, R. P. (1992). Reading rate: Theory, research, and practical implications. Journal of Reading, 36, 84-95.

Chang, A. (2012). Improving reading rate activities for EFL students: Timed reading and repeated oral reading. Reading in a Foreign Language, 24, 1, 56-83. 
Chang, A. \& College, H. (2010). The effect of a timed reading activity on EFL learners: Speed, comprehension, and perceptions. Reading in a Foreign Language, 22, 2, 284-303.

Chuang, R., Malatesha, J., \& Quentin, D. (2014). Corss-language transfer of reading ability: evidence from Taiwanese ninth-grade adolescents. Journal of Literacy Research, 44, 1, 97-119.

Comeau, L., Cormier, P., Grandmaison, E., \& Lacroix, D. (1999). A longitudinal study of phonological processing skills in children learning to read in a second language. Journal of Educational Psychology, 91(1), 22-43.

D’Angiulli, A., Siegel, L. S., \& Serra, E. (2001). The development of reading in English and Italian in bilingual children. Applied Psycholinguistics, 22, 479-507.

Da Fontoura, H. A., \& Siegel, L. S. (1995). Reading, syntactic and working memory skills of bilingual Portuguese-English Canadian children. Reading and Writing: An Interdisciplinary Journal, 7, 139-153.

Durgunoglu, A. Y., Nagy, W. E., \& Hancin, B. J. (1993). Cross-language transfer of phonemic awareness. Journal of Educational Psychology, 85, 453-465.

Durgunoglu, A. Y., Mir, M., \& Ariño-Martí, S. (1993). The relationship between bilingual children's reading and writing in their two languages. In S. Randsdell \& M. L. Barbier (Eds.), Psycholinguistic approaches to understanding second language writing (pp. 81-100). Dordrecht: Kluwer.

Durgunoglu, A. (2002). Cross-linguistic transfer in literacy development and implications for language learning. Annals of Dyslexia, 52(1), 189-204.

Fujita, K. \& Yamashita, J. (2014). The relations and comparisons between reading comprehension and reading rate of Japanese high school EFL learners. The Reading Matrix, 14, 2, 34-49.

Gholamain, M., \& Geva, E. (1999). The concurrent development of word recognition skills in English and Farsi. Language Learning, 49, 183-217.

Gómez-Domínguez, M. (2016). Fluidez lectora oral en inglés como lengua extranjera. Tonos Digital, Revista de Estudios Filológicos, 31.

Gottardo, A. (2002). The relationship between language and reading skills in bilingual Spanish-English speakers. Topics in Language Disorders, 22(5), 46-70.

Grabe, W. (2009). Reading in a second language. Cambridge: Cambridge University Press.

Hamada, M., \& Koda, K. (2008). Influence of first language orthographic experience on second language decoding and word learning. Language Learning 58, 1-31.

Hasbrouck, J., \& Tindal, G. (2006). Oral reading fluency norms: A valuable assessment tool for reading teachers. International Reading Association, 636-644.

He, M. (2014). Does extensive reading promote reading speed? The Reading Matrix, 14, 1, 16-25. 
Hirai, A. (1999). The relationship between listening and reading rates of Japanese EFL learners. The Modern Language Journal, 83, 367-384.

Huffman, J. (2014). Reading rate gains during a one-semester extensive reading course. Reading in a Foreign Language, 26, 2, 17-33.

Iwahori, Y. (2008). Developing reading fluency: A study of extensive reading in EFL. Reading in a Foreign Language, 20, 70-91. Laberge \& Samuels, 1974

Jainta S, Kapoula Z (2011) Dyslexic children are confronted with unstable binocular fixation while reading. PLoS One 6(4): e18694.

Joh, J. \& Plakans, L. (2017). Working memory in L2 reading comprehension: The influence of prior knowledge. System, 70, 107-120.

Lai, F-K. (1993). The effect of a summer reading course on reading and writing skills. System, 21, 87-100.

Lallier, M., Acha, J., \& Carreiras, M. (2016). Cross-linguistic interactions influence reading development in bilinguals: a comparison between early balanced French-Basque and Spanish-Basque bilingual children. Developmental Science, $19,1,76-89$.

Lindsey, K. A., Manis, F. R., \& Bailey, C. E. (2003). Prediction of first-grade reading in Spanish-speaking English-language learners. Journal of Educational Psychology, 95, 482-494.

López, D. \& Sabé, M. (2008). Guia didàctica. Quaderns d'eficàcia lectora. Barcelona: La Galera.

Macalister, J. (2010). Speed reading course and their effect on reading authentic texts: A Preliminary investigation. Reading in a Foreign Language, 22, 1, 104-116.

Matsui, T., \& Noro, T. (2010). The effects of 10-minute sustained silent reading on junior high school EFL learners' reading fluency and motivation. Japan Society of English Language Education, 71-80.

McCollum, J. (2012). The Correlation of Arab ELLs' Academic Reading Fluency in Arabic and English (Unpublished MA thesis). Provo, UT: Brigham Young University.

McLean, S. \& Rouault, G. (2017). The effectiveness and efficiency of extensive reading at developing reading rates. System, 70, 92-106.

Morris, D. (2008). Diagnosis and correction of reading problems. New York: Guilford.

Nassaji, H. (2003). Higher-level and lower-level text processing skills in advanced ESL reading comprehension. The Modern Language Journal, 87, 261-276. 
Nassaji, H. (2014). The role and importance of lower-level processes in second language reading. Language Teaching, 47, 1-37.

Nuttall, C. (2005). Teaching Reading Skills in a Foreign Language. Oxford, UK: Macmillan Education.

Rasinski, T. V. (2000). Speed does matter in reading. The Reading Teacher, 54, 146-151.

Raymond, P., \& Parks, S. (2002). Transitions: Orienting to reading and writing assignments in EAP and MBA contexts. The Canadian Modern Language Review, 59, 152-180.

Robb, T. N., \& Susser, B. (1989). Extensive reading vs. skills building in an EFL context. Reading in a Foreign Language, 5, 239-251.

Segalowitz, N., Poulsen, C., \& Komoda, M. (1991). Lower level components of reading skill in higher level bilinguals: Implications for reading instruction. AILA Review, 8, 15-30.

Sheu, S. P.-H. (2003). Extensive reading with EFL readers at beginning level. TESL Reporter, 36, 8-26.

Stanovich, K. E. (1986). Matthew effects in reading: some consequences of individual differences in the acquisition of literacy. Reading Research Quarterly, XXI, 4, 360-407.

Sun-Alperin, M. K. \& M. Wang (2011). Cross-language transfer of phonological and orthographic processing skills from Spanish L1 to English L2. Reading and Writing 24, 591-614.

Taguchi, E., \& Gorsuch, G. J. (2002). Transfer effects of repeated EFL reading on reading new passages: A preliminary investigation. Reading in a Foreign Language, 14, 43-65.

Taguchi, E., Takayasu-Maass, M., \& Gorsuch, G. (2004). Developing reading fluency in EFL: How assisted repeated reading and extensive reading affect fluency development. Reading in a Foreign Language, 16, 70-96.

Wang, M., Park, Y. J., \& Lee, K. R. (2006). Korean-English biliteracy acquisition: Cross language and orthography transfer. Journal of Educational Psychology, 98, 148-158.

Webb, S., \& Chang, C.-S. (2012). Vocabulary learning through assisted and unassisted repeated reading. The Canadian Modern Language Review, 68, 276-290.

Webb, S., \& Chang, A. (2014). Second language vocabulary learning through extensive reading with audio support: How do frequency and distribution of occurrence affect learning? Language Teaching Research, 1-2.

Wurr, A. (2003). Reading in a second language: A reading problem or a language problem? Journal of college reading and learning, 33, 2, 157-169. 


\section{APPENDIX A}

Summary of the studies that have examined L2 silent reading rates

Table 1

Main characteristics of the studies exploring L2 silent reading rates at the pre-test

\begin{tabular}{|c|c|c|c|c|c|}
\hline Study & $\begin{array}{l}\text { N \& } \\
\text { participants'age }\end{array}$ & L1 & $\mathbf{L 2}$ & Treatment & $\begin{array}{l}\text { L2 rates } \\
(\mathrm{WPM})\end{array}$ \\
\hline Chang (2012) & $\mathrm{N}=35,22-48$ & Taiw & Eng & TR \& RR & $102-83$ \\
\hline $\begin{array}{l}\text { Chang \& College } \\
\text { (2010) }\end{array}$ & $\mathrm{N}=84$, college sts & n.a. & Eng & TR \& CONT & $118-124$ \\
\hline $\begin{array}{l}\text { Beglar et al. } \\
(2012)\end{array}$ & $\mathrm{N}=97,19-20$ & Jap & Eng & IR \& ER & $87.54-89 / 103$ \\
\hline $\mathrm{He}(2014)$ & $\mathrm{N}=66,15-17$ approx. & Chin & Eng & ER & $134-230$ \\
\hline Hirai (1999) & $\mathrm{N}=56$, college sts & Jap & Eng & $\begin{array}{l}\text { Cross- } \\
\text { sectional }\end{array}$ & 139 \\
\hline Iwahori (2008) & $\mathrm{N}=33,16-17$ & Jap & Eng & ER & $84-112$ \\
\hline Bell (2001) & $\mathrm{N}=26$, young adults & Arab & Eng & ER & 68 \\
\hline Lai (1993) & $\mathrm{N}=266,11-15$ & Chin & Eng & n.a & 85 \\
\hline $\begin{array}{l}\text { Rob \& Susser } \\
(1989)\end{array}$ & $\mathrm{N}=125$, university & Jap & Eng & ER \& Skills & $\begin{array}{l}\text { Skills: } 78 \\
\text { EXP: } 79\end{array}$ \\
\hline Sheu (2003) & $\mathrm{N}=98,13-14$ & Chin & Eng & ER \& CG & $59.7-85.2$ \\
\hline $\begin{array}{l}\text { Taguchi et al. } \\
\text { (2004) }\end{array}$ & $\begin{array}{l}\mathrm{N}=20, \text { mostly } 18(19 \\
\& 60)\end{array}$ & Jap & Eng & As RR\& ER & $84.84-80.88$ \\
\hline $\begin{array}{l}\text { Taguchi \& } \\
\text { Gorsuch (2002) }\end{array}$ & $\mathrm{N}=18$, university & Jap & Eng & RR & 113 \\
\hline Huffman (2014) & $\begin{array}{l}\mathrm{N}=66, \text { univ, }(19 / 20 \\
\text { yo) }\end{array}$ & Jap & Eng & ER \& IR & $\begin{array}{l}\text { ER } 110 \\
\text { IR } 103\end{array}$ \\
\hline $\begin{array}{l}\text { Beglar \& Hunt } \\
\text { (2014) }\end{array}$ & $\begin{array}{l}\mathrm{N}=76, \text { univ }(19 / 20 \\
\text { yo })\end{array}$ & Jap & Eng & PLES READ & 97 \\
\hline $\begin{array}{l}\text { Fujita \& } \\
\text { Yamashita } \\
(2014)\end{array}$ & $\begin{array}{l}N=125, \text { high school } \\
(15-16)\end{array}$ & Jap & Eng & $\begin{array}{l}\text { Cross- } \\
\text { sectional }\end{array}$ & 93.8 \\
\hline $\begin{array}{l}\text { Matsui \& Noro } \\
\text { (2010) }\end{array}$ & $\begin{array}{l}\mathrm{N}=122 \text {, junior high } \\
\text { school }(12-15)\end{array}$ & Jap & Eng & ER\& CG & $\begin{array}{l}\text { ER } 88.57 \\
\text { CG } 89.29\end{array}$ \\
\hline $\begin{array}{l}\text { McLean \& } \\
\text { Rouault (2017) }\end{array}$ & $\begin{array}{l}\mathrm{N}=50 \text {, first year } \\
\text { university students }\end{array}$ & Jap & Eng & $\begin{array}{l}\text { ER \& } \\
\text { Grammar- } \\
\text { Translation }\end{array}$ & $\begin{array}{l}\text { ER } 99.38 \\
\text { GRAM } 97.79\end{array}$ \\
\hline $\begin{array}{l}\text { McCollum } \\
\text { (2012) }\end{array}$ & $\begin{array}{l}\mathrm{N}=112 \text {, university } \\
\text { students }(18-22)\end{array}$ & Arab & Eng & $\begin{array}{l}\text { Cross- } \\
\text { sectional }\end{array}$ & $127-166$ \\
\hline
\end{tabular}

n. $a .=$ not acknowledged; $T R=$ timed reading; $E R=$ extensive reading; $I R=$ intensive reading; $R R=$ repeated reading; $C G=$ control group 


\section{APPENDIX B}

Texts used to examine the participants' reading skills in their L1 and L2

Catalan

En David era un noi de vint anys que tan sols feia una setmana que treballava com a il·lustrador en una important revista gràfica. La feina l'apassionava i, encara que reconeixia que mai no l'hauria aconseguit sense la influència del seu pare -un destacat banquer de la ciutat que es deia com ell, David García-, havia decidit agafar-se a aquella oportunitat sense dubtar-ho i lluitar amb totes les forces per guanyar-se un lloc, ell tot sol, en el difícil món de la il·lustració. De moment, durant aquella primera setmana de feina, havia servit més cafès que dibuixos havien sortit de la seva ploma, àvida d'una oportunitat. Però en David no era impacient. Al contrari, tothom el considerava un noi sensat, molt segur d'ell mateix, i posseïdor d'un caràcter amable i tranquil. En David abandonà la redacció a les set de la tarda. S'aturà al quiosc de la cantonada. Es va treure tres monedes de la butxaca i va comprar un diari. Els altres dies, després de la feina, se n'anava de dret a casa, però aquell dia era divendres i en David havia quedat amb uns amics per anar al cinema.

Spanish

David era un chico de veinte años que solo hacía una semana que trabajaba como ilustrador en una importante revista gráfica. Era un oficio que le apasionaba y, aunque reconocía que no lo habría conseguido nunca sin la influencia de su padre -un destacado banquero de la ciudad que se llamaba como él, David García-, había decidido aferrarse a aquella oportunidad sin dudar y luchar con todas sus fuerzas para ganarse un nombre, él solo, en el difícil mundo de la ilustración. De momento, durante aquella primera semana de trabajo, había servido más cafés que dibujos había trazado su pluma, ávida de alguna oportunidad. Pero David no era impaciente. Al contrario, todo el mundo lo consideraba un muchacho sensato, seguro de sí mismo, y con un carácter amable y tranquilo. David abandonó la redacción a las siete de la tarde. Se detuvo en el quiosco de la esquina. Sacó tres monedas de su bolsillo y compró un periódico. A diario, al salir del trabajo, se iba directo a casa, pero aquel día era viernes y David había acordado ir al cine con unos amigos.

\section{English}

Fred is in his bedroom. He has some homework but he's looking out of the window. It's raining and very windy. Suddenly Fred sees something in the garden!

It's round and grey. It's a SPACESHIP! Then he sees a little ET and a robot coming down the stairs of the spaceship!

Fred opens the window. The ET talks to Fred. 
ET: Hello! I'm PB3. I'm from Planet PB3. This is my robot Robin.

Fred: Hello! My name is Frederick but you can call me Fred.

PB3 sees an apple on Fred's desk. It's a red apple. He's very surprised. On Planet P3 they don't have apples and they don't have red things! On Planet P3 the only colours are black, grey, green and white.

Fred, PB3 and Robin go to the kitchen. Fred shows PB3 and Robin some other fruit. He shows them a pear and some grapes, a banana and an orange. He shows them some vegetables too. There are potatoes and beans and a bowl of peas. PB3 and Robin are very happy.

Next day PB3 and Robin go with Fred to the village to buy some fruit and vegetables. PB3 and Robin hide in a box next to a shop. Fred buys lemons and carrots and PB3 and Robin watch from their box. They are very surprised! 


\section{APPENDIX C}

Results Regression with L2 rates as the dependent variable and Grade and L1 rates as independent variables

\begin{tabular}{|c|c|c|c|c|c|}
\hline Model & $\begin{array}{l}\text { Unstan } \\
\text { coeffic } \\
\text { B }\end{array}$ & $\begin{array}{l}\text { dized } \\
\text { Std. Error }\end{array}$ & $\begin{array}{l}\text { Standardized } \\
\text { coefficients } \\
\text { Beta }\end{array}$ & $\mathbf{t}$ & Sig. \\
\hline Constant & 48,026 & 3,522 & & 13,635 & ,000 \\
\hline Grade &, 080 & ,393 & ,006 & ,204 & ,838 \\
\hline WPM_L1 & ,233 &, 011 & 619 & 21,964 &, 000 \\
\hline
\end{tabular}

Results of the regression analyses for each grade.

Grade 5

\begin{tabular}{|c|c|c|c|c|c|}
\hline \multirow[t]{2}{*}{ Model } & \multicolumn{2}{|c|}{$\begin{array}{l}\text { Unstandardized } \\
\text { coefficients }\end{array}$} & \multirow[t]{2}{*}{$\begin{array}{l}\text { Standardized } \\
\text { coefficients }\end{array}$} & \multirow[t]{2}{*}{$\mathbf{t}$} & \multirow[t]{2}{*}{ Sig. } \\
\hline & $\mathrm{B}$ & td. Error & & & \\
\hline Constant & 37,009 & 3,390 & & 10,916 & ,000 \\
\hline WPM_L1 & ,281 & ,029 &, 743 & 9,862 &, 000 \\
\hline
\end{tabular}

Grade 6

\begin{tabular}{|c|c|c|c|c|c|}
\hline \multirow[t]{2}{*}{ Model } & \multicolumn{2}{|c|}{$\begin{array}{l}\text { Unstandardized } \\
\text { coefficients }\end{array}$} & \multirow[t]{2}{*}{$\begin{array}{c}\text { Standardized } \\
\text { coefficients }\end{array}$} & \multirow[t]{2}{*}{$\mathbf{t}$} & \multirow[t]{2}{*}{ Sig. } \\
\hline & $\mathrm{B}$ & td. Error & & & \\
\hline Constant & 55,920 & 4,283 & & 13,055 &, 000 \\
\hline WPM_L1 & , 165 & ,033 & ,501 & 4,986 &, 000 \\
\hline
\end{tabular}

Grade 7 


\begin{tabular}{|c|c|c|c|c|c|}
\hline \multirow[t]{2}{*}{ Model } & \multicolumn{2}{|c|}{$\begin{array}{l}\text { Unstandardized } \\
\text { coefficients }\end{array}$} & \multirow{2}{*}{$\begin{array}{c}\begin{array}{c}\text { Standardized } \\
\text { coefficients }\end{array} \\
\text { Beta }\end{array}$} & \multirow[t]{2}{*}{$\mathbf{t}$} & \multirow[t]{2}{*}{ Sig. } \\
\hline & B & Std. Error & & & \\
\hline Constant & 46,368 & 3,771 & & 12,296 &, 000 \\
\hline WPM_L1 & ,264 & ,029 & ,584 & 9,229 &, 000 \\
\hline
\end{tabular}

Grade 8

\begin{tabular}{|c|c|c|c|c|c|}
\hline Model & $\begin{array}{l}\text { Unstan } \\
\text { coeffici } \\
\text { B }\end{array}$ & $\begin{array}{l}\text { dized } \\
\text { Std. Error }\end{array}$ & $\begin{array}{l}\text { Standardized } \\
\text { coefficients } \\
\text { Beta }\end{array}$ & $\mathbf{t}$ & Sig. \\
\hline Constant & 52,868 & 2,775 & & 19,054 &, 000 \\
\hline WPM_L1 & ,237 & ,022 & 687 & 10,619 &, 000 \\
\hline
\end{tabular}

Grade 9

\begin{tabular}{|c|c|c|c|c|c|}
\hline Model & $\begin{array}{l}\text { Unstan } \\
\text { coeffici } \\
\text { B }\end{array}$ & $\begin{array}{l}\text { dized } \\
\text { Std. Error }\end{array}$ & $\begin{array}{l}\text { Standardized } \\
\text { coefficients } \\
\text { Beta }\end{array}$ & $\mathbf{t}$ & Sig. \\
\hline Constant & 53,587 & 3,088 & & 17,355 &, 000 \\
\hline WPM_L1 & ,215 &, 025 & ,597 & 8,572 &, 000 \\
\hline
\end{tabular}

Grade 10

Model

Unstandardized
coefficients

\section{Standardized}

$\mathbf{t}$

Sig. coefficients 


\begin{tabular}{l|lllll} 
& B & Std. Error & Beta & \\
Constant & 49,991 & 2,209 & & 22,631 &, 000 \\
WPM_L1 &, 178 &, 023 &, 581 & 7,876 &, 000
\end{tabular}

Grade 11

\begin{tabular}{|c|c|c|c|c|c|}
\hline Model & $\begin{array}{l}\text { Unstan } \\
\text { coeffic } \\
\text { B }\end{array}$ & $\begin{array}{l}\text { dized } \\
\text { Std. Error }\end{array}$ & $\begin{array}{l}\text { Standardized } \\
\text { coefficients } \\
\text { Beta }\end{array}$ & $\mathbf{t}$ & Sig. \\
\hline Constant & 56,717 & 6,683 & & 8,486 & ,000 \\
\hline WPM_L1 & ,146 & 057 & ,374 & 2,553 &, 000 \\
\hline
\end{tabular}

Grade 12

\begin{tabular}{|c|c|c|c|c|c|}
\hline Model & $\begin{array}{l}\text { Unstan } \\
\text { coeffic } \\
\text { B }\end{array}$ & $\begin{array}{l}\text { dized } \\
\text { Std. Error }\end{array}$ & $\begin{array}{l}\text { Standardized } \\
\text { coefficients } \\
\text { Beta }\end{array}$ & $\mathbf{t}$ & Sig. \\
\hline Constant & 38,225 & 2,976 & & 12,844 & ,000 \\
\hline WPM_L1 & ,274 &, 025 & ,892 & 11,175 &, 000 \\
\hline
\end{tabular}




\title{
본느
}

ISSN: $2340-8685$

Investigaciones Sobre Lectura

\section{La lectura en inglés como lengua extranjera: Examinando diferencias en fluidez lectora, comprensión, eficacia i la influencia de la $L 1$ entre cursos}

\author{
Àngels Llanes Baró \\ Universidad de Lleida
}

\section{Resumen}

Leer en una segunda lengua o lengua extranjera (L2) es un proceso más complicado que leer en la primera lengu (L1) a ya que requiere más del lector. El proceso de lectura puede ser evaluado desde varios dominios. La fluidez lectora es conocida por ser el factor más determinante a la hora de identificar problemas de lectura (Rasinski, 2000). No obstante, el objetivo de leer es la comprensión de un texto, por esta razón la comprensión no debería ser ignorada. A pesar de la importancia de leer en una L2, pocos estudios se han centrado en examinar sus efectos. El objetivo de este estudio es triple: primero, establecer unos valores medios de fluidez lectora en la L2 de un grupo de estudiantes Catalanes/Españoles de diferentes edades y cursos; segundo, examinar si hay diferencias significativas entre los participantes de diferentes cursos en cuanto a fluidez, comprensión y eficacia lectora; y tercero, explorar si la fluidez en la L1 está correlacionadas con la fluidez en la L2 y, en caso afirmativo, hasta qué punto la fluidez lectora en la L1 explica la de la L2.

790 estudiantes Catalanes/Españoles aprendices de inglés participaron en este estudio. Los cursos de los participantes oscilan des de $5^{\circ}$ de primaria (12 años) hasta $2^{\circ}$ de bachillerato (18 años). Los estudiantes leyeron dos textos, uno en inglés y el otro en catalán o castellano (podían elegir). Después de leer el texto contestaron a siete preguntas de comprensión (tipo elección múltiple). Sus resultados de fluidez (palabras por minuto), comprensión (porcentaje de texto entendido) y eficacia (una fórmula que integra velocidad y comprensión) fueron obtenidos automáticamente después de contestar las preguntas. Los resultados muestran que la fluidez y la comprensión lectora no son lineares y que estas variables no mejoran necesariamente con el tiempo. Los resultados también exponen que la fluidez lectora en la L1 y la L2 están altamente correlacionadas y que la fluidez en la L1 explica un largo porcentaje de la fluidez en la L2.

Palabras clave: fluidez lectora en L2, fluidez lectora en L1, leer en una lengua extranjera, curso, comprensión lectora en L2 


\section{Introducción}

Leer es una de las habilidades más importantes ya que es esencial para formar parte de la sociedad actual: nos da acceso a la información y al conocimiento. Leer es una actividad compleja que supone, de manera general, dos niveles de procesamiento. El procesamiento de componentes de nivel inferior ("lower level") tiene que ver con el reconocimiento de las palabras y se centra en la identificación de las letras, la correspondencia entre grafema y morfema, y la asociación de palabras con sus significados. El procesamiento de componentes de nivel superior ("higher level") tiene que ver con la sintaxis y la integración de información textual, y éste incluye procesos tales como la resolución de ambigüedades del texto, conectar palabras con sus referentes y la integración de las ideas con el conocimiento general del lector (Nassaji, 2003; Segalowitz, Poulsen \& Komoda, 1991).

La lectura puede ser evaluada desde varios dominios, siendo la fluidez lectora uno de éstos, probablemente el más determinante para la identificación de un problema de lectura. Tal como reivindicaba Rasinski (2002), la fluidez lectora es crucial para la identificación de un proceso de lectura ineficiente, aunque la comprensión sea satisfactoria. Aunque la comprensión es el objetivo principal de leer, la fluidez lectora no debería ser ignorada porque nos da información de cómo procesamos un texto: un lector ineficiente va a pasarse mucho más tiempo leyendo el mismo texto que un lector eficiente (asumiendo que la comprensión de ambos es adecuada), y esto conlleva frustración y desmotivación a la hora de leer y, consecuentemente, a leer mucho menos (Gómez-Domínguez, 2016; Jainta and Kapoula, 2011; Stanovich, 1986).

Leer en una segunda lengua o lengua extranjera (L2) puede ser incluso aún más complicado porque requiere más esfuerzo por parte del lector (Wurr, 2003), por eso leer lentamente puede afectar, entre otras cosas, a las lecturas obligatorias de los estudiantes de cursos específicos, especialmente a nivel de universidad. Raymond y Parks (2002, p.161) encontraron que los estudiantes de una segunda lengua " read $50 \%$ or less in their MBA textbooks on a regular basis because they had too much to read, read very slowly, and thus lacked the necessary time to read" (leyeron regularmente el 50\% o menos de los libros del Máster en Administración y Empresas porque tenían demasiados textos para leer, porque leían muy lentamente, y consecuentemente les faltaba tiempo para de leer). A pesar de la importancia de leer en una L2, pocos estudios se han centrado en examinar sus efectos.

El objetivo de este estudio es triple: primero, proporcionar el valor medio aproximado de fluidez lectora en inglés como lengua extranjera de estudiantes catalanes/españoles de diferentes edades y cursos; en segundo lugar, este estudio pretende examinar si hay diferencias significativas entre participantes de diferentes cursos en cuanto a fluidez, comprensión y eficacia lectora; y tercero, este artículo pretende explorar si la fluidez lectora de los estudiantes en su lengua materna está correlacionada con las de su segunda lengua y, en caso afirmativo, cuánto influye la fluidez lectora de la primera lengua a la fluidez de la segunda.

\section{Revisión de la literatura}

Hay pocos estudios que analicen las habilidades lectoras en una L2 y, la poca investigación que ha examinado la fluidez lectora se centra en: a) fluidez lectora en una 
L2 como resultado de un programa de lectura en esa lengua (la mayoría con estudiantes universitarios), y b) el reconocimiento de palabras de la L2 (decodificación) como resultado de habilidades específicas, como memoria operativa y conciencia fonológica, utilizadas cuando leemos en nuestra primera lengua. Mientras que los estudios que examinan la fluidez lectora antes y después de un programa de lectura normalmente examinan las palabras leídas por minuto (usando textos), el reconocimiento de palabras leídas tiene que ver con la habilidad decodificar palabras o sílabas sueltas teniendo en cuenta la influencia de la L1 de los participantes.

Fluidez lectora en una L2 como resultado de la participación en un programa de lectura

La mayoría de estudios que analizan la lectura en una L2 se han centrado en los efectos que un curso específico de lectura tiene en el desarrollo de la L2. Estos programas incluyen lectura extensiva (extensive reading), lectura y audición simultáneas (reading while listening), lectura sola (reading only), lectura repetida (repeated reading) y lectura cronometrada (timed reading). En todos los casos, la investigación previa demuestra que todos estos programas afectan positivamente al desarrollo de la L2 en la mayoría de las habilidades como, por ejemplo, en la fluidez lectora (Chang, 2012; Iwahori, 2008; Taguchi et al., 2004), el vocabulario (Webb \& Chang, 2012; Webb \& Chang, 2014) y comprensión (Beglar, Hunt, \& Kite, 2012; Nuttall, 2005).

Existen pocos estudios que se centren en la fluidez lectora de una L2, y la mayoría examinan el desarrollo de la fluidez en estudiantes universitarios (Beglar et al., 2012; Huffman, 2014; McLean \& Rouault, 2017; Rob \& Susser, 1989). Sólo se conocen seis estudios que hayan investigado la fluidez lectora en adolescentes, y cinco de ellos lo han hecho después de un tratamiento de lectura extensiva (ver Apéndice A para una revisión de los estudios que han explorado la fluidez lectora en una L2). Uno de los primeros estudios en investigar el desarrollo de la lectura con adolescentes fue Lai (1993). Lai exploró los efectos que un curso de verano de lectura extensiva podía tener en la comprensión y la fluidez de sus participantes, un grupo de 266 chinos aprendices de inglés (L2) en cursos 7-9 (11-15 años). Lai encontró que en general los participantes mejoraban significativamente la comprensión y la fluidez lectora (con una media de 85 palabras por minuto [PPM] en el pre-test y de 181 PPM en el pos-test). Otro investigador que documentó los efectos que la lectura extensiva puede tener en la comprensión y la fluidez lectora de un grupo de adolescentes fue Sheu (2003). Sheu comparó dos grupos de estudiantes de inglés, también chinos, de 13-14 años de edad (unos leyeron lecturas clasificadas por nivel y el otro leyeron libros escritos para niños nativos de inglés), con un grupo que seguía el procedimiento tradicional. En cuanto a la fluidez lectora, Sheu (2003) encontró que los participantes de los tres grupos mejoraron significativamente del pre-test al pos-test, pero que los participantes de los grupos experimentales mejoraron más la fluidez y comprensión lectora que los participantes del grupo control, con valores de 59 PPM en el pre-test y 95 en el pos-test para los que leían libros clasificados por nivel, y 98 PPM en el pre-test y 136 en el pos-test los participantes que leían libros para niños nativos ingleses. Más evidencia positiva de los efectos de un programa de lectura extensiva en los adolescentes proviene de Iwahori 
(2008). Los participantes de Iwahori eran 33 japoneses de 16-17 años, estudiantes de inglés, a quien se les dio libros clasificados por nivel y los cuales se tuvieron que leer durante las 7 semanas de duración del estudio. Los participantes mejoraron su fluidez lectora de 84 PPM en el pre-test a 112 en el pos-test, una mejora que fue significativa. Similarmente, Matsui y Noro (2010) investigaron los efectos de un curso de lectura extensiva en la fluidez de un grupo de adolescentes. Los autores compararon la fluidez durante un año escolar de dos grupos de estudiantes japoneses estudiantes de inglés, uno que seguía el curso de lectura extensiva que incluía 10 minutos de lectura al principio de la clase $(n=60)$ y el otro que seguía el procedimiento tradicional y no incluía lectura extensiva $(n=62)$. Los autores encontraron que el grupo de lectura extensiva mejoró significativamente su fluidez, mientras que el grupo control no, y la diferencia entre los grupos fue significativa. El grupo experimental leyó una media de 88.57 PPM en el pretest y 108.32 en el pos-test, mientras que el grupo control leyó a una media de 89.29 PPM en el pre-test y 94.79 en el pos-test. He (2014) investigó la relación entre lectura extensiva y fluidez lectora. Más concretamente, He comparó la mejora en fluidez lectora de dos grupos ( $\mathrm{n}=33$ cada uno) de estudiantes chinos aprendices de inglés, uno practicaba la lectura extensiva y no se le indicó cuánto tenía que leer (lectura libre), y el otro también era de lectura extensiva, pero a los estudiantes se les indicó cuánto tenían que leer (lectura integrativa). Ambos grupos mejoraron su velocidad lectora pero el grupo de lectura integrativa mejoró más que el grupo de lectura libre; el primero leyó 139 PPM en el pre-test y 210 en el pos-test, mientras que el segundo leyó 145 PPM en el pre-test y 212 en el pos-test. Un último estudio que examinó la fluidez lectora y la comprensión en la L2 de estudiantes adolescentes es Fujita y Yamashita (2014). Aun así, estos autores no reportaron los efectos de un programa de lectura, sino que realizaron un estudio transversal sobre la relación de la fluidez y comprensión lectora de la L2 de un grupo de 125 japoneses estudiantes de inglés. Los autores encontraron que fluidez y comprensión lectora estaban significativamente correlacionadas, aunque la relación era débil.

Así, los estudios mencionados sobre L2 fluidez lectora son variables: los participantes de He (2014) y Fujita y Yamashita (2014) son de edades comparables pero su fluidez lectora es bastante diferente (los primeros demostraron una fluidez media de 135 PPM mientras que los segundos una fluidez media de 93 PPM). Además, la mayoría de los estudios que examinan la fluidez lectora en una L2 se han llevado a cabo con adultos y la mayoría en Asia (ver Apéndice A); sólo seis han documentado la fluidez lectora de adolescentes estudiantes de inglés, y ninguno de niños. Así, uno de los objetivos de este estudio es llenar esta laguna informando de la meda de fluidez, comprensión y eficacia lectora en inglés (L2) de un grupo de catalanes/españoles, de diferentes edades (10-18). Aunque hay diferentes escalas aceptadas de fluidez cuando en una L1 (Bisquerra, 1994; Hasbrouck \& Tindal, 2006; Morris, 2008), no hay escala para estudiantes de una lengua extranjera (L2). Una vez esté establecida la fluidez lectora media, otro objetivo del estudio es examinar si hay diferencias significativas entre los participantes de diferentes edades y cursos, y si su fluidez en la L1 está relacionada con la fluidez en la L2.

Reconocimiento de palabras en la L2 como resultado de una habilidad específica involucrada en la lectura de la L1

La influencia interlingüística de la lectura ha sido examinada y comprobada por varios investigadores (Durgunoglu, 2002; Lallier et al., 2016; Nassaji, 2014). Se sabe que leer en una L2 es más complicado que leer en la L1 porque en la L2 los estudiantes 
empiezan a estudiar cuando ya son expertos, o casi expertos, en su L1 (excepto en casos de niños bilingües y otros casos particulares); así, éstos ya tienen un vocabulario extenso y un buen control de la L1. Además, es común empezar a aprender a leer en una L2 cuando los estudiantes aún están en estados iniciales de su aprendizaje, por eso su nivel de competencia es aún bajo. La influencia que la L1 tiene en las habilidades lectoras de la L2 ha sido identificada en dominios tales como la conciencia fonológica, la conciencia sintáctica, la decodificación de palabras y la ortografía, entre otras (Grabe, 2009).

La conciencia fonológica consiste en identificar y manipular los constituyentes morfológicos de una palabra. Los estudios que se centran en la transferencia intralingüística de la conciencia fonológica sugieren que ésta está relacionada con el reconocimiento de palabras y su ortografía (Adams, 1990). Un estudio dirigido por Bialystok et al. (2003) examinó la conciencia fonológica y la decodificación de palabras de tres grupos con participantes de 5-6 años: un grupo de niños monolingües de inglés, un grupo de niños monolingües de chino, y un grupo de niños bilingües de inglés y chino que estaban empezando a aprender a leer en inglés (L2). Los autores encontraron que la conciencia fonológica estaba relacionada con la exposición al lenguaje y a la instrucción del mismo, y que se transfería entre las lenguas tanto en los bilingües como los estudiantes de L2.

En cuanto a la decodificación, algunos estudios como el de Durgunoglu et al. (1993) examinaron los factores que afectan la identificación de palabras en inglés por parte de españoles estudiantes de inglés con un nivel inicial. Los autores analizaron el nombramiento letras, la conciencia fonémica del español, el reconocimiento de palabras en inglés y español, y su competencia general en inglés y español. Los resultados muestran que la conciencia fonémica y el reconocimiento de palabras en español afectaban las capacidades de reconocer palabras y pseudo-palabras en inglés. De la misma manera, Da Fontoura y Siegel (1995) examinaron la naturaleza del lenguaje, la memoria y las habilidades lectoras de un grupo de ingleses (L1) estudiantes de portugués. Los autores encontraron que la decodificación transfería entre lenguas; los niños que tenían notas bajas de lectura en inglés, también las tenían en portugués. No obstante, estos autores encontraron que, en términos de conciencia sintáctica, los lectores con más habilidades sólo se diferenciaban de los monolingües en que los bilingües tenían notas significantemente más bajas en su conciencia sintáctica en inglés. La conciencia sintáctica también fue examinada por Abu-Rabia (1995). Sus participantes, 143 niños árabes de 8-11 años, fueron sometidos a varias pruebas que les fueron administradas midiendo su memoria operativa, reconocimiento de palabras, ortografía, y ataque de palabra. Los autores encontraron que el reconocimiento de palabras estaba significativamente correlacionado con sus habilidades fonológicas, su proceso semántico, conocimiento sintáctico y la memoria operativa. Los lectores ineficientes mostraron un retraso significativo en estas áreas, especialmente a nivel fonológico y semántico.

Finalmente, en términos de memoria operativa, varios estudios han mostrado que factores cognitivos como la memoria operativa juegan un papel muy importante 
(Alptekin \& Erçetin, 2009; Joh \& Plakans, 2017). Uno de estos estudios es el de Gholamain y Geva (1999), quienes investigaron los efectos de factores cognitivos como la memoria operativa en inglés, la memoria operativa de estudiantes de persa (L2), su fluidez en nombrar las letras, su nivel de competencia oral en persa en el reconocimiento de palabras en inglés, y la decodificación de pseudo-palabras persas. Los autores encontraron que las habilidades cognitivas básicas estaban correlacionadas entre lenguas y que las mismas variables cognitivas pronosticaban significativamente el reconocimiento de las palabras y pseudo-palabras en inglés y persa.

El número de estudios que examinan elementos discretos implicados en la lectura, como la memoria operativa y la conciencia fonológica, son escasos y se centran en influencias interlingüísticas de habilidades como la fluidez lectora (de un texto), y muy pocos, si es que existe alguno, se centran en examinar la fluidez lectora silenciosa en la lengua extranjera de niños de edad escolar. Como este tipo de participantes aún está desarrollando sus habilidades lectoras en la L1, esto debería proveer un entendimiento de las relaciones interlingüísticas y la fluidez lectora.

\section{Método}

El presente estudio intenta llenar tres lagunas en el área de lectura en la L2 respondiendo las siguientes preguntas:

1. ¿Cuál es la media de fluidez lectora silenciosa en inglés como L2, de estudiantes catalanes /españoles de diferentes cursos?

2. ¿Existen diferencias significativas entre los participantes de los diferentes cursos en fluidez, comprensión y eficiencia lectora?

3. ¿Está la fluidez lectora en la L1 relacionada con la fluidez lectora en la L2?

3.1. En caso afirmativo, ¿qué porcentaje de la fluidez lectora en la L2 explica la fluidez en la L1?

\section{Participantes}

790 estudiantes ( $n=393$ hombres, $n=397$ mujeres) de $5^{\circ}$ de primaria a $2^{\circ}$ de bachillerato participaron en el presente estudio. Los estudiantes son bilingües de catalán y castellano, con edades comprendidas de 10 a 18 años, y estudian inglés como L2. Los participantes con algún trastorno de aprendizaje como la dislexia o con un nivel bajo de catalán o castellano fueron excluidos del estudio. Los datos de los estudiantes de primaria $(n=157)\left(\operatorname{cursos} 5^{\circ}\right.$ y $\left.6^{\circ}\right)$ provienen de tres escuelas diferentes de Cataluña (ver tabla 1 para ver las características de las escuelas), mientras que los demás participantes $(n=633)$ provienen de cuatro institutos diferentes. En total este estudio cuenta con 81 participantes de $5^{\circ}$ de primaria (curso 5), 76 de $6^{\circ}$ de primaria (curso 6), 168 de $1^{\circ}$ de ESO (curso 7), 128 de $2^{\circ}$ de ESO (curso 8), 135 de $3^{\circ}$ de ESO (curso 9), 125 de $4^{\circ}$ ESO (curso 10), 42 de $1^{\circ}$ de bachillerato (curso 11), y 35 de $2^{\circ}$ de bachillerato (curso 12). Se incluyó información de los estudiantes en centros de características diferentes (rurales, urbanos, públicos, concertados). Los participantes de los centros que participaron en este estudio provienen de la clase social media. Todos ellos fueron informados según ley de que participaban en un proyecto de investigación. Sin embargo, el tema del estudio no se especificó para no alterar los resultados. 
Tabla 1. Características de las instituciones

\begin{tabular}{|c|c|c|c|c|}
\hline Escuela/Insti & Cursos & Tipo de escuela/insti & n estudiantes (curso) & Total estudiantes \\
\hline \multirow[t]{2}{*}{ VS } & $5-6$ & Público \& rural & $\mathrm{n}=25$ & $\mathrm{n}=40$ \\
\hline & & & $\mathrm{n}=15(6)$ & \\
\hline \multirow[t]{6}{*}{ EC } & $5-10$ & Concertado \& urbano & $\mathrm{n}=36(5)$ & $\mathrm{n}=211$ \\
\hline & & & $\mathrm{n}=38(6)$ & \\
\hline & & & $\mathrm{n}=40(7)$ & \\
\hline & & & $\mathrm{n}=46(8)$ & \\
\hline & & & $\mathrm{n}=27(9)$ & \\
\hline & & & $\mathrm{n}=24(10)$ & \\
\hline \multirow[t]{6}{*}{ MM } & $5-10$ & Concertado \& rural & $\mathrm{n}=20(5)$ & $\mathrm{n}=186$ \\
\hline & & & $\mathrm{n}=23(6)$ & \\
\hline & & & $\mathrm{n}=41(7)$ & \\
\hline & & & $\mathrm{n}=30$ & \\
\hline & & & $\mathrm{n}=39(9)$ & \\
\hline & & & $\mathrm{n}=33(10)$ & \\
\hline \multirow[t]{6}{*}{$\overline{\text { LPU }}$} & $7-12$ & Público \& rural & $\mathrm{n}=87(7)$ & $\mathrm{n}=353$ \\
\hline & & & $\mathrm{n}=52(8)$ & \\
\hline & & & $\mathrm{n}=69(9)$ & \\
\hline & & & $\mathrm{n}=68(10)$ & \\
\hline & & & $\mathrm{n}=42(11)$ & \\
\hline & & & $\mathrm{n}=35(12)$ & \\
\hline
\end{tabular}

\section{Instrumento y procedimiento}

Con el fin de recoger los datos, se les pidió a los participantes que leyeran un texto en su L1 (catalán o español) y uno en inglés (L2). El texto en la L1 era un pasaje narrativo de un libro escrito para estudiantes a partir de 10 años. Este libro fue publicado en catalán y en español y su traducción fue realizada por la misma autora. El texto en catalán tenía 192 palabras y el de español 185 (ver Apéndice B).

El texto en inglés era un pasaje narrativo que fue seleccionado de un libro que pertenecía a un nivel A1 y contenía 220 palabras. Este nivel fue elegido porque estudios 
anteriores demuestran que uno de los requisitos para analizar la fluidez lectora es la idoneidad del texto: el texto tiene que encajar en el nivel de los estudiantes (Carver, 1990; Huffman, 2014). El índice Flesh-Kincaid, índice de legibilidad, indicó un índice de 91,7, lo que significa que es muy fácil de leer y no es difícil para los estudiantes más jóvenes. Los dos textos fueron administrados a través de un ordenador. Después de leer cada texto, los participantes contestaron siete preguntas de comprensión general. Los textos y sus preguntas fueron previamente pilotados y pocos cambios fueron hechos (por ejemplo en el texto L1 estaba escrita la palabra "peseta" y esta fue cambiada a "moneda"). Para compensar los efectos de esta prueba, la mitad de los participantes empezaron leyendo el texto en L1 y la otra mitad en inglés. Los mismos textos fueron utilizados para todos los participantes porque investigaciones anteriores demuestran la necesidad de poder comparar "groups with differing amounts of time studying the L2 using the same test" (grupos con diferentes niveles de instrucción en la L2 utilizando la misma prueba) (Chuang et al., 2014, p. 113).

Los participantes realizaron la prueba en el aula de informática, allí se les dio la dirección de la página web donde se encontraba la prueba. El test fue individual (había un ordenador por estudiante) y los estudiantes tenían que leer los textos en silencio y a su ritmo normal. La investigadora enfatizó la necesidad de estar concentrados y de empezar a leer tan pronto como apareciera el texto. Los estudiantes también fueron informados que después de cada texto tendrían que contestar unas preguntas de comprensión. Los participantes primero seleccionaron el texto (catalán/español o inglés) que tenían que leer primero. Cuando clicaban al botón "start" el texto aparecía y el cronómetro comenzaba, aunque no lo podían ver y no se les dijo en ningún momento el tema de nuestra investigación, así que los resultados no fueron influenciados. Una vez leído el texto, tenían que pulsar el botón "finish" (automáticamente el cronómetro se paraba) y las preguntas de comprensión aparecían automáticamente. Estas preguntas estaban escritas en la L1 de los participantes, incluso las del texto en inglés, para asegurarnos que si las respondían incorrectamente no era porque no entendían la pregunta. Una vez aparecían las preguntas, ya no era posible volver atrás y releer el texto. Las preguntas de comprensión consistían en siete preguntas de elección múltiple con cuatro posibles respuestas y sólo una opción correcta. Después de contestar las preguntas y guardar las respuestas, las siguientes medidas fueron obtenidas.

\section{Medidas}

Se obtuvieron cuatro medidas. La primera fue las palabras leídas por minuto (PPM), la cual fue calculada automáticamente teniendo en cuenta la extensión del texto y el tiempo total que tardaron en leerlo. Dos medidas de comprensión fueron incluidas: el número de respuestas correctas (siete en total) y el porcentaje de comprensión, que fue calculado mediante la siguiente fórmula: número de aciertos*100/7. La última medida fue la eficacia lectora, que es una fórmula que incluye la velocidad y la comprensión ([PPM* \% comprensión]/100) (Álvarez, 1993; López \& Sabé, 2008). Para la eficacia, la nota máxima que los estudiantes podían obtener era igual que valor de PPM, pero ésto sólo afecta al valor máximo, puesto que los participantes fueron penalizados por cada error de comprensión y por lo tanto la eficacia nunca puede ser mayor que la fluidez; por ejemplo, un participante que lee 85 PPM tendría un resultado de 85 para su eficacia lectora, asumiendo que él/ella haya contestado todas las preguntas correctamente. 


\section{Resultados}

La primera pregunta de investigación, que intentaba establecer la fluidez media de lectura en voz baja en inglés para los participantes de cada curso, fue contestada mediante la estadística descriptiva para los 8 cursos diferentes. La media y la desviación estándar por PPM, comprensión (porcentaje) y eficacia fueron calculadas para los participantes en cada curso, como se puede ver en la tabla 2

Tabla 2. Estadística descriptiva para cada una de las medidas en inglés

\begin{tabular}{lllll}
\hline Curso & Edad & PPM & Comprensión (\%) & Eficacia \\
5 & $10-11$ & $65.06(24.64)$ & $82.14(18.3)$ & $52.12(25.5)$ \\
6 & $11-12$ & $74.71(20.37)$ & $82.38(17.98)$ & $59.24(21.16)$ \\
7 & $12-13$ & $75.79(32.02)$ & $83.57(16.38)$ & $62.62(29.16)$ \\
8 & $13-14$ & $77.46(29.79)$ & $83.04(17.82)$ & $64.55(30.79)$ \\
9 & $14-15$ & $76.81(26.51)$ & $89.04(13.84)$ & $67.85(25.74)$ \\
10 & $15-16$ & $64.35(18.9)$ & $90.46(14.3)$ & $57.96(20)$ \\
11 & $16-17$ & $71.85(31.7)$ & $90.01(14.7)$ & $64.79(32.1)$ \\
12 & $17-18$ & $65.66(21.39)$ & $97(6)$ & $63.46(20.89)$ \\
\hline & & & & \\
\hline
\end{tabular}

Para contestar la segunda pregunta, que preguntaba si existían diferencias significativas entre cursos, tres ANOVAs de un factor fueron calculadas, cada una con curso como variable independiente pero con diferentes variables dependientes: PPM, comprensión (porcentaje) y eficacia, respectivamente. El ANOVA con PPM como variable dependiente indicó que había diferencias significativas entre los cursos $(\mathrm{F}(7$, $800)=3855), p=.006)$. Las comparaciones post-hoc utilizando el test Tukey HSD indicaron que la media para los cursos 7,8 y 9 eran significativamente más altas que para los de curso 10, y estas diferencias tenían un tamaño del efecto medio según la $d$ de Cohen: 0.43 (cursos 7-10), 0.52 (cursos 8-10) y 0.54 (cursos 9-10). El ANOVA con comprensión como variable dependiente también indicó que había diferencias significativas entre los cursos $(\mathrm{F}(7,800)=10073, \mathrm{p}=.000)$, y las comparaciones posthoc con el test Tukey HSD mostraron que las medias del curso 5 eran significativamente más bajas que la de los cursos 9,10, 11 y 12, que las medias el curso 6 también eran significativamente más bajas que la de los cursos 9, 10, 11 y 12, que las 
de curso 7 eran significativamente más bajas que las de los cursos 10,11, y 12, y que las medias del curso 8 también eran significativamente más bajas que las de los cursos 9 , 10,11 y 12 . Tal y como muestra la tabla 3 , estas diferencias eran medias excepto la diferencia entre el curso 12 y los demás, que era grande. Finalmente, el ANOVA con eficacia como variable dependiente también demostró ser estadísticamente significativo $(\mathrm{F}(7,800)=2885, \mathrm{p}=.006)$. El análisis post-hoc indicó que la media del curso 5 era significativamente más baja que la de los cursos 9 y 11. Sin embargo, la diferencia entre las medias de eficacia en inglés resultó ser pequeña $(d=0.25$ cursos $5-9$ y $d=0,12$ cursos 5-11).

Tabla 3. Tamaño del efecto para Comprensión según la $d$ de Cohen

\begin{tabular}{lllll}
\hline Grades & $\mathbf{9}$ & $\mathbf{1 0}$ & $\mathbf{1 1}$ & $\mathbf{1 2}$ \\
$\mathbf{5}$ & 0.42 & 0.50 & 0.47 & 1.09 \\
$\mathbf{6}$ & 0.41 & 0.49 & 0.46 & 1.09 \\
$\mathbf{7}$ & - & 0.44 & 0.41 & 1.09 \\
$\mathbf{8}$ & 0.37 & 0.45 & 0.42 & 1.04
\end{tabular}

Finalmente, con el fin de responder la tercera pregunta de investigación, que preguntaba si la fluidez lectora en la L2 estaba relacionada con la fluidez lectora en la L1, se utilizaron diferentes correlaciones bivariadas entre PPM en la L2 y en la L1 para los estudiantes de cada curso. Como se puede apreciar en la Tabla 4, la fluidez lectora entre las dos lenguas siempre está correlacionada significativamente, esta correlación es especialmente fuerte para los cursos 5 y 12, débiles para el nivel 11 y moderada para los demás.

Tabla 4. Correlaciones entre PPM en la L2 y la L1 para cada curso

\begin{tabular}{|c|c|c|c|c|c|c|c|c|}
\hline Curso & 5 & 6 & 7 & 8 & 9 & 10 & 11 & 12 \\
\hline Correlación & $.476 * * *$ & $.501 * *$ & $.576^{* *}$ & $.687 * *$ & $.597 * *$ & $.581 * *$ & $.374^{*}$ & $.832 * *$ \\
\hline $\mathbf{p}$ & .000 & .000 & .000 & .000 & .000 & .000 & .015 & .000 \\
\hline $\mathbf{n}$ & 86 & 76 & 184 & 128 & 135 & 124 & 42 & 34 \\
\hline
\end{tabular}

Para contestar la sub-pregunta número 3.1, la cual preguntaba sobre el porcentaje de fluidez lectora de la L2 explicado por curso y fluidez lectora en la L1, se utilizó una regresión linear estándar. Se encontró que curso sólo explicaba un $6 \%$ del modelo, mientras que la fluidez lectora en la L1 explicaba un $61,9 \%$ de la fluidez lectora en la L2 (ver Apéndice C).

A continuación, se realizaron una serie de regresiones lineares para cada nivel, con la fluidez lectora en la L2 como variable dependiente y la fluidez lectora en la L1 como variable independiente. Se encontró que para todos los niveles la fluidez lectora en la L1 explicaba un porcentaje muy alto de la fluidez lectora en la L2, con valores oscilando entre $37.4 \%$ para el curso 11 y $89.2 \%$ para el curso 12 (ver apéndice C para resultados más detallados). 


\section{Discusión y conclusión}

La primera pregunta de investigación pretendía establecer unas medias de fluidez lectora silenciosa en inglés (L2) para los alumnos de distintos cursos. Debido a la ausencia de estudios relacionados con la fluidez lectora en la L2 con estudiantes de primaria, la fluidez lectora de los participantes en los cursos 5 y 6 no se pudo comparar con ningún estudio previo. No obstante, la fluidez lectora de los participantes de los cursos 7-9 es comparable, aunque un poco inferior, con la de los participantes de Lai (1993) y Matsui y Noro (2010). La fluidez lectora de los estudiantes del curso 8 es más alta que la encontrada en el estudio de Sheu (2003), quien también incluyó participantes del curso 8 cuya fluidez lectora era incluso más baja que la de los estudiantes de curso 5 de este estudio. Estudios previos que analizan la fluidez lectora en la L2 con estudiantes universitarios también han encontrado velocidades muy distintas entre los participantes. Los participantes en Hirai (1999), por ejemplo, mostraron velocidades que variaban entre 60 y 139 PPM; los participantes en Beglar et al. (2012) e Iwahori (2008) muestran velocidades parecidas (87-104 PPM y 84-112 PPM, respectivamente). Sin embargo, otros estudios con estudiantes universitarios han reportado velocidades lectoras más bajas, tales como 68 PPM (Bell, 2001), 78 WPM (Robb y Susser, 1989), y 64 PPM (Taguchi et al., 2004) y estas velocidades son incluso más bajas que las de los estudiantes de los cursos 5 y 6 del presente estudio. Este estudio demuestra que la fluidez lectora en la L2 es muy variable y que el curso no garantiza necesariamente más rapidez o más eficiencia lectora (de acuerdo con McCollum, 2012), pero parece garantizar mejor comprensión lectora. Esto se debe probablemente a la dificultad de leer en una L2, lo cual está influido por muchos aspectos como la habilidad lectora en la L1 (ver abajo), el conocimiento de vocabulario en la L2, la capacidad de decodificar el texto en la L2 y la distancia entre la L1 y la L2 entre otros. En este aspecto, cabe destacar que prácticamente todos los estudios que examinan el efecto de un programa de lectura en la fluidez lectora en la L2 incluyen lenguas que son muy distantes (japoneses y chinos estudiando inglés), mientras que este estudio incluye dos lenguas que son más cercanas (catalán/español e inglés) y que comparten alfabeto (aunque entre ellas haya diferencias en la correspondencia de los fonemas y los morfemas).

La segunda pregunta de investigación pretendía examinar si había diferencias significativas entre los participantes de los diferentes cursos en cuanto a fluidez, comprensión y eficacia lectora en la L2. Se esperaba que los participantes de cursos más elevados leyeran más rápido y mejor, y que su comprensión fuera mayor que los participantes de cursos más bajos dado que los participantes mayores han recibido más horas de instrucción en inglés y, consecuentemente, han estado expuestos a la L2 más que los participantes más jóvenes; además, se supone que los participantes mayores deberían tener un mejor control sobre las habilidades de procesamiento del los componentes de procesamiento de nivel inferior (lower level skills) explicadas anteriormente, las cuales incluyen la decodificación. No obstante, pocas diferencias significativas entre grupos fueron encontradas en relación a la fluidez lectora, y las pocas diferencias significativas favorecían a los participantes más jóvenes (las únicas diferencias significativas fueron entre participantes de curso 10, quienes leían significantemente más lentamente que los participantes de los cursos 7,8 y 9). Los 
análisis descriptivos mostraron que los participantes de los cursos 10 y 12 leían prácticamente a la misma velocidad que los participantes de nivel 5. La información de los estudiantes de niveles 11 y 12 se tiene que mirar con cautela porque estos eran dos grupos pequeños de un solo instituto $\mathrm{y}$, por esta razón, la información no puede ser generalizada. La información de los estudiantes de nivel 10 proviene de 125 estudiantes de tres institutos diferentes, públicos y concertados. El hecho que los estudiantes de curso 10 leyeran prácticamente a la misma velocidad que los de curso $5 \mathrm{y}$ de manera similar a los estudiantes de los otros cursos sugiere que quizás los participantes más jóvenes están mejor preparados que los mayores (quizás están más expuestos al inglés de manera extracurricular, como mirar dibujos o jugar al ordenador). Este hallazgo sugiere que, independientemente de su curso o edad, los estudiantes que aprenden inglés como L2 en países como España, donde la exposición a la lengua está prácticamente limitada a la clase de inglés (3-4 horas por semana), necesitarán mucho más tiempo para leer con fluidez en la L2 dado que la fluidez lectora más rápida encontrada fue de 77.46 PPM (estudiantes de curso 8). Este índice está lejos de las 200 PPM sugeridas (Anderson, 2008; Carver, 1992). Además, si recordamos que el curso no garantiza la mejora en la fluidez lectora en una L2, la mayoría de estos estudiantes necesitarán invertir mucho tiempo en leer en la L2; leer es probablemente la habilidad más indispensable para los alumnos a nivel universitario, y esto podría desmotivar o privar a aquéllos que en algún momento irán a la universidad y se les requerirá leer en la L2 para llevar a cabo otras tareas dada la cantidad de tiempo que necesitarán pasarse leyendo. Dado que estudios previos han demostrado la eficiencia de los programas de lectura (algunos de los estudiantes adolescentes en Lai (1993) experimentaron una mejora de 96 PPM, la cual es más alta que ninguna de las velocidades encontradas en los estudiantes del presente estudio), se le tendría que dar mayor importancia a la lectura en las escuelas con tal de mejorar la fluidez de los participantes. En cuanto a la comprensión, esta medida es la que muestra la mayoría de diferencias significativas entre grupos, con los estudiantes mayores obteniendo resultados más altos que los más jóvenes. Una posible explicación para este resultado podría ser que los participantes mayores tienen un conocimiento de vocabulario más extenso y probablemente un nivel de competencia más alto (han recibido clases en inglés durante más años que los participantes jóvenes) $\mathrm{y}$, por eso, es posible que ellos entendieran los textos significativamente mejor. Otra posible explicación a este resultado es que los participantes mayores supuestamente leen mejor también en la L1 y es posible que haya una transferencia positiva de la L1, afectando los procesos de nivel inferior y consecuentemente es posible que ellos no tuvieran que centrar su atención en estos procesos de nivel inferior como decodificar y que pudieran concentrarse más en la comprensión (Nassaji, 2013; Segalowitz, Poulsen \& Komoda, 1991; Taguchi \& Gorsuch, 2002). Sin embargo, cabe destacar que las primeras diferencias significativas en comprensión no aparecieron hasta el curso 9 (el cual es significativamente diferente de los cursos 5 y 6), sugiriendo que los estudiantes en una escuela o en un instituto que siguen un programa tradicional sin centrarse en la lectura necesitarán bastantes años de instrucción en inglés antes de notar una diferencia significativa en comprensión.

Finalmente, con respecto a la eficacia en la L2 se encontró que los estudiantes del curso 5 leen menos eficazmente que aquéllos de los cursos 9 y 11 . La fluidez lectora y la comprensión de los estudiantes de curso 5 eran más bajas que aquéllas de los estudiantes de los cursos 9 y 11. Como se ha mencionado anteriormente, esto podría haber ocurrido como consecuencia de que los alumnos mayores posiblemente tengan más ventaja en cuanto a la identificación de las letras y la asociación de las palabras con su significado, y también por la posibilidad que los mayores tienen un nivel general más 
alto y un conocimiento del léxico más extenso ya que han recibido más años de enseñanza y exposición a la L2. El hecho que sólo dos cursos (9 y 11) se han diferenciado del curso 5 indica que la eficacia (o la velocidad lectora basada en la comprensión) también es similar entre niveles cuando no hay un interés especial en la lectura, y que varios años de instrucción en inglés no garantizan leer (significativamente) mejor.

Así pues, parece que la fluidez lectora y la eficacia no son tan sensibles como la comprensión cuando se trata de mejorar la lectura en una L2. Este hallazgo no es inesperado dado que las escuelas incluidas en este estudio no tenían un enfoque específico en la lectura y que, como la mayoría de las escuelas de enseñanza tradicional en España, centran su enseñanza básicamente en la gramática y el vocabulario. Además, los estudiantes normalmente hacen exámenes de lectura pero éstos consisten en entender un texto ya que se les pide contestar a unas preguntas de comprensión o resumir lo que el texto dice; por esta razón, los estudiantes probablemente pusieron más atención a la comprensión que a la velocidad ya que su fluidez lectora (en inglés) nunca antes ha sido examinada.

La tercera pregunta de investigación pretendía investigar si la fluidez lectora en la L2 estaba relacionada con la de la L1 y qué porcentaje de fluidez en la L1 era explicado por curso y la fluidez en la L1. Se encontró que para los participantes de todos los niveles, la fluidez lectora en la L1 estaba significativamente correlacionada con la fluidez en la L2, y que la fluidez en la L1 explicaba un largo porcentaje de la fluidez en la L2 para los participantes de todos los cursos. Aprender a leer en una L2 es un proceso que recibe ayuda de la transferencia de conocimiento y habilidades de la lectura en la L1 (Nassaji, 2014). Dado que "certain literacy concepts and strategies [...] can be universal and operate across languages" (ciertos conceptos literarios y estrategias [...] pueden ser universales y operar entre lenguas) (Durgunoglu, 2002, p. 192), "some insights and skills learned in one language need to be learned only once, after which time they can be applied to other languages being learned" (algunos conocimientos y habilidades aprendidas en una lengua tienen que ser aprendidas sólo una vez, después de la cual se pueden aplicar a varias de las lenguas que se estén aprendiendo) (Bourgoin, 2014 , p. 358). Este resultado se puede explicar con la Hipótesis de Automaticidad (Laberge \& Samuels, 1974), la cual dice que el lector necesita llevar a cabo los procesos de identificación de bajo nivel (lower level), como por ejemplo decodificar palabras, con la mínima atención ya que la capacidad de memoria operativa es limitada y, por esta razón, si el lector disminuye el tiempo dedicado a la decodificación de palabras, podrá poner más atención a otros aspectos como la comprensión. Estudios previos confirman que los lectores de una L2 confían en su conocimiento de proceso ortográfico en la L1 cuando procesan textos en la L2 (Hamada \& Koda, 2008; Sun-Alperin \& Wang, 2011). Esta transferencia fonológica de multilenguaje ha estado documentada con estudiantes con diferentes L1s aprendiendo inglés como L2 (francés: Comeau, Cormier, Grandmaison, \& Lacroix, 1999; italiano: D'Angiulli, Siegel, \& Serra, 2001; coreano: Wang, Park, \& Lee, 2006; español: Durgunoglu et al., 1993), y corrobora resultados previos que han encontrado que las habilidades de procesamiento fonológico del español predicen la habilidad de leer palabras en inglés (Gottardo, 2002; Lindsey et al., 
2003) y su ortografía (Bryant et al., 1990). Hallazgos previos sugieren que la diferencia entre L1 y L2 es clara con estudiantes de nivel inicial e intermedio, pero a medida que la competencia va mejorando, los procesos implicados en la lectura en L1 y L2 se hacen más similares. Así, el hecho que en todos los cursos la fluidez lectora de los participantes en la L1 estuviera significativamente correlacionada con su fluidez en la L2 indica que los participantes en este estudio no tenían un nivel avanzado en la L2 sino que eran mayoritariamente principiantes o estudiantes de nivel intermedio.

El presente estudio ha intentado establecer valores de fluidez lectora en inglés como L2 para estudiantes de diferentes cursos, explorar si existían diferencias significativas en términos de fluidez, comprensión y eficacia lectora entre participantes de diferentes cursos, y si la fluidez lectora en la L2 estaba correlacionada con la fluidez en la L1 y, en caso afirmativo, hasta qué punto qué porcentaje de fluidez lectora en la L1 explica la fluidez lectora en la L2. Se encontró que los participantes leen a una velocidad que oscila entre 65.05 y 77.46 PPM, y que, estar estudiando en un curso más elevado no garantiza leer más rápido o más eficientemente en inglés. Similarmente, se han encontrado pocas diferencias significativas entre los niveles en términos de fluidez y eficacia, y la mayoría de diferencias existen en la comprensión, la cual favorece a los estudiantes mayores. Finalmente, la fluidez lectora de los participantes en la L1 está significativamente correlacionada con su fluidez lectora en la L2 y su fluidez en la L1 explica un largo porcentaje de su fluidez en la L2. Si uno acepta el valor de 200 PPM sugerida por conocidos investigadores como un objetivo razonable, estos resultados son poco prometedores ya que los participantes que mostraron un valor más alto leían menos de la mitad de palabras por minuto (77.46 PPM) incluso cuando el texto en la L2 era muy básico, y más años de instrucción en inglés sin un enfoque específico en la lectura no parece garantizar una lectura más rápida o eficiente. Dado que estudios previos que examinan los efectos de diferentes programas de lectura han demostrado que implementar un programa de lectura específico como lectura extensiva o lectura cronometrada conlleva a leer más rápido y entender más, más programas de lectura tendrían que ser implementados en las escuelas con tal de mejorar las habilidades lectoras de los estudiantes en la L2. Sin embargo, a pesar de que muchas investigaciones han encontrado diferencias significativas a favor de esos estudiantes en cursos de lectura específicos, la calidad-precio de dichos programas podría ser cuestionada dado que implementar un programa de lectura significaría una inversión económica considerable (i.e. materiales y muchas veces equipamientos adicionales serían necesarios) y los resultados pueden ser variables puesto que algunos estudios previos han encontrado una mejora dramática en fluidez lectora, pero otros sólo han encontrado mejoras modestas.

Finalmente, como la fluidez lectora en la L1 está correlacionada con la de la L2 y la primera explica un porcentaje alto de la lectura en la L2, otra implicación pedagógica de este estudio sería que la fluidez lectora en la L1 no tendría que ser ignorada porque no sólo indican los posibles problemas de lectura en la L1 sino también en la L2. Dado que este hallazgo sugiere que la fluidez no es específica de una lengua, la velocidad lectora tendría que ser más importante en el plan de estudios de nuestras instituciones.

Este estudio también tiene una implicación metodológica, la cual deriva del hallazgo que la fluidez y eficacia lectora no muestran diferencias significativas así como lo hace la comprensión. Muchos estudios previos han encontrado que leer más rápido nos lleva a entender más (Iwahori 2008; Macalister, 2010), pero otros no han 
encontrado ninguna relación entre ambos dominios. Este estudio apunta a la dirección que cuando se lee en la L2 estas medidas se desarrollan de maneras distintas y que no están necesariamente relacionadas la una con la otra. Más investigación es necesaria para clarificar esto, pero si confirma que estas dos medidas no están relacionadas, los profesores y los organizadores de los programas de lectura deberían tener en cuenta estos resultados. En cualquier caso, sería interesante que periódicamente se revisara la fluidez lectora en la L1 y la L2 con el fin de detectar posibles problemas de lectura antes que sea demasiado tarde y que los estudiantes se muestren desmotivados y, consecuentemente, paren de leer y de acceder a información o conocimientos en la L2.

Agradecimientos

Este estudio ha sido financiado por la beca FFI2016-80576-P y por la Beca Iberoamérica del Banco Santander para Jóvenes Profesores Investigadores 2014. Me gustaría agradecer a mi colega Elsa Tragant su feedback sobre una versión previa de este manuscrito y a mi colega Raquel Serrano por su ayuda con la versión en español. Me gustaría dar las gracias a Judith Borràs por su ayuda con la traducción al español.

\section{Referencias}

Abu-Rabia, S. (1995). Learning to read in Arabic: Reading, syntactic, orthographic and working memory skills in normally achieving and poor Arabic readers. Reading Psychology, 16 (4), 351-394.

Adams, M. J. (1990). Beginning to read: Thinking and learning about print. Cambridge, MA: MIT Press.

Alptekin, C. \& Erçetin, G. (2009). Assessing the relationship of working memory to L2 reading: Does the nature of comprehension process and reading span task make a difference? System, 37, 4, 627-639.3

Álvarez, C. M. (1993). Técnicas de lectura eficaz. Revista interuniversitaria de formación del profesorado, 18, 83-91.

Anderson, N. J. (2008). Practical English language teaching: Reading. New York: McGraw-Hill.

Beglar, D. \& Hunt, A. (2014). Pleasure reading and reading rate gains. Reading in a foreign language, 26, 29-48.

Beglar, D., Hunt, A., \& Kite, Y. (2012). The effect of pleasure reading on Japanese university EFL learners' reading rates. Language Learning, 62, 665-703.

Bell, T. (2001). Extensive reading: Speed and comprehension. The Reading Matrix, 1. 
Bialystok, E., McBride-Chang, C., \& Luk, G. (2005). Bilingualism, language proficiency, and learning to read in two writing systems. Journal of Educational Psychology, 97 (4), 580-590.

Bisquerra, R. (1994). Eficiència lectora. La mesura per al seu desenvolupament. Exercicis $i$ barems. Madrid: Centro de Estudios ADAMS.

Bourgoin, R. (2014). The predictive effects of L1 and L2 early literacy indicators on reading in French immersion. The Canadian Modern Languge Review, 70, 3, 355-380.

Bryant, P. E., MacLean, M., Bradley, L. L., \& Crossland, J. (1990). Rhyme and alliteration, phoneme detection, and learning to read. Developmental Psychology, 26, 429-438.

Carver, R. P. (1990). Reading rate: A review of research and theory. New York: Academic Press.

Carver, R. P. (1992). Reading rate: Theory, research, and practical implications. Journal of Reading, 36, 84-95.

Chang, A. (2012). Improving reading rate activities for EFL students: Timed reading and repeated oral reading. Reading in a Foreign Language, 24, 1, 56-83.

Chang, A. \& College, H. (2010). The effect of a timed reading activity on EFL learners: Speed, comprehension, and perceptions. Reading in a Foreign Language, 22, 2, 284-303.

Chuang, R., Malatesha, J., \& Quentin, D. (2014). Corss-language transfer of reading ability: evidence from Taiwanese ninth-grade adolescents. Journal of Literacy Research, 44, 1, 97-119.

Comeau, L., Cormier, P., Grandmaison, E., \& Lacroix, D. (1999). A longitudinal study of phonological processing skills in children learning to read in a second language. Journal of Educational Psychology, 91(1), 22-43.

D’Angiulli, A., Siegel, L. S., \& Serra, E. (2001). The development of reading in English and Italian in bilingual children. Applied Psycholinguistics, 22, 479-507.

Da Fontoura, H. A., \& Siegel, L. S. (1995). Reading, syntactic and working memory skills of bilingual Portuguese-English Canadian children. Reading and Writing: An Interdisciplinary Journal, 7, 139-153.

Durgunoglu, A. Y., Nagy, W. E., \& Hancin, B. J. (1993). Cross-language transfer of phonemic awareness. Journal of Educational Psychology, 85, 453-465.

Durgunoglu, A. Y., Mir, M., \& Ariño-Martí, S. (1993). The relationship between bilingual children's reading and writing in their two languages. In S. Randsdell \& M. L. Barbier (Eds.), Psycholinguistic approaches to understanding second language writing (pp. 81-100). Dordrecht: Kluwer.

Durgunoglu, A. (2002). Cross-linguistic transfer in literacy development and implications for language learning. Annals of Dyslexia, 52(1), 189-204. 
Fujita, K. \& Yamashita, J. (2014). The relations and comparisons between reading comprehension and reading rate of Japanese high school EFL learners. The Reading Matrix, 14, 2, 34-49.

Gholamain, M., \& Geva, E. (1999). The concurrent development of word recognition skills in English and Farsi. Language Learning, 49, 183-217.

Gómez-Domínguez, M. (2016). Fluidez lectora oral en inglés como lengua extranjera. Tonos Digital, Revista de Estudios Filológicos, 31.

Gottardo, A. (2002). The relationship between language and reading skills in bilingual Spanish-English speakers. Topics in Language Disorders, 22(5), 46-70.

Grabe, W. (2009). Reading in a second language. Cambridge: Cambridge University Press.

Hamada, M., \& Koda, K. (2008). Influence of first language orthographic experience on second language decoding and word learning. Language Learning 58, 1-31.

Hasbrouck, J., \& Tindal, G. (2006). Oral reading fluency norms: A valuable assessment tool for reading teachers. International Reading Association, 636-644.

He, M. (2014). Does extensive reading promote reading speed? The Reading Matrix, 14, $1,16-25$.

Hirai, A. (1999). The relationship between listening and reading rates of Japanese EFL learners. The Modern Language Journal, 83, 367-384.

Huffman, J. (2014). Reading rate gains during a one-semester extensive reading course. Reading in a Foreign Language, 26, 2, 17-33.

Iwahori, Y. (2008). Developing reading fluency: A study of extensive reading in EFL. Reading in a Foreign Language, 20, 70-91.Laberge \& Samuels, 1974.

Jainta S, Kapoula Z (2011) Dyslexic children are confronted with unstable binocular fixation while reading. PLoS One 6(4): e18694.

Joh, J. \& Plakans, L. (2017). Working memory in L2 reading comprehension: The influence of prior knowledge. System, 70, 107-120.

Lai, F-K. (1993). The effect of a summer reading course on reading and writing skills. System, 21, 87-100.

Lallier, M., Acha, J., \& Carreiras, M. (2016). Cross-linguistic interactions influence reading development in bilinguals: a comparison between early balanced French-Basque and Spanish-Basque bilingual children. Developmental Science, 19, 1, 76-89. 
Lindsey, K. A., Manis, F. R., \& Bailey, C. E. (2003). Prediction of first-grade reading in Spanish-speaking English-language learners. Journal of Educational Psychology, 95, 482-494.

López, D. \& Sabé, M. (2008). Guia didàctica. Quaderns d'eficàcia lectora. Barcelona: La Galera.

Macalister, J. (2010). Speed reading course and their effect on reading authentic texts: A Preliminary investigation. Reading in a Foreign Language, 22, 1, 104-116.

Matsui, T., \& Noro, T. (2010). The effects of 10-minute sustained silent reading on junior high school EFL learners' reading fluency and motivation. Japan Society of English Language Education, 71-80.

McCollum, J. (2012). The Correlation of Arab ELLs' Academic Reading Fluency in Arabic and English (Unpublished MA thesis). Provo, UT: Brigham Young University.

McLean, S. \& Rouault, G. (2017). The effectiveness and efficiency of extensive reading at developing reading rates. System, 70, 92-106.

Morris, D. (2008). Diagnosis and correction of reading problems. New York: Guilford.

Nassaji, H. (2003). Higher-level and lower-level text processing skills in advanced ESL reading comprehension. The Modern Language Journal, 87, 261-276.

Nassaji, H. (2014). The role and importance of lower-level processes in second language reading. Language Teaching, 47, 1-37.

Nuttall, C. (2005). Teaching Reading Skills in a Foreign Language. Oxford, UK: Macmillan Education.

Rasinski, T. V. (2000). Speed does matter in reading. The Reading Teacher, 54, 146151.

Raymond, P., \& Parks, S. (2002). Transitions: Orienting to reading and writing assignments in EAP and MBA contexts. The Canadian Modern Language Review, 59, 152-180.

Robb, T. N., \& Susser, B. (1989). Extensive reading vs. skills building in an EFL context. Reading in a Foreign Language, 5, 239-251.

Segalowitz, N., Poulsen, C., \& Komoda, M. (1991). Lower level components of reading skill in higher level bilinguals: Implications for reading instruction. AILA Review, 8, 15-30.

Sheu, S. P.-H. (2003). Extensive reading with EFL readers at beginning level. TESL Reporter, 36, 8-26.

Stanovich, K. E. (1986). Matthew effects in reading: some consequences of individual differences in the acquisition of literacy. Reading Research Quarterly, XXI, 4, 360-407. 
Sun-Alperin, M. K. \& M. Wang (2011). Cross-language transfer of phonological and orthographic processing skills from Spanish L1 to English L2. Reading and Writing 24, 591-614.

Taguchi, E., \& Gorsuch, G. J. (2002). Transfer effects of repeated EFL reading on reading new passages: A preliminary investigation. Reading in a Foreign Language, 14, 43-65.

Taguchi, E., Takayasu-Maass, M., \& Gorsuch, G. (2004). Developing reading fluency in EFL: How assisted repeated reading and extensive reading affect fluency development. Reading in a Foreign Language, 16, 70-96.

Wang, M., Park, Y. J., \& Lee, K. R. (2006). Korean-English biliteracy acquisition: Cross language and orthography transfer. Journal of Educational Psychology, $98,148-158$.

Webb, S., \& Chang, C.-S. (2012). Vocabulary learning through assisted and unassisted repeated reading. The Canadian Modern Language Review, 68, 276-290.

Webb, S., \& Chang, A. (2014). Second language vocabulary learning through extensive reading with audio support: How do frequency and distribution of occurrence affect learning? Language Teaching Research, 1-2.

Wurr, A. (2003). Reading in a second language: A reading problem or a language problem? Journal of college reading and learning, 33, 2, 157-169. 
Apéndice A

Resumen de los estudios que han examinado la fluidez lectora en silencio

Características principales de los estudios que han examinado la fluidez lectora en silencio en una L2 (pre-test)

\begin{tabular}{|c|c|c|c|c|c|}
\hline Estudio & $\begin{array}{l}\text { N \& edad } \\
\text { participantes }\end{array}$ & L1 & $\mathbf{L 2}$ & Tratamiento & $\begin{array}{l}\text { Velocidad en la } \\
\text { L2 (PPM) }\end{array}$ \\
\hline Chang (2012) & $\mathrm{N}=35,22-48$ & Taiw & Ing & TR \& RR & $102-83$ \\
\hline $\begin{array}{l}\text { Chang \& College } \\
\text { (2010) }\end{array}$ & $\mathrm{N}=84$, universitarios & n.s. & Ing & TR \& CONT & $118-124$ \\
\hline $\begin{array}{l}\text { Beglar et al. } \\
(2012)\end{array}$ & $\mathrm{N}=97,19-20$ & Jap & Ing & IR \& ER & 87.54- 89/103 \\
\hline He (2014) & $\mathrm{N}=66,15-17$ aprox. & Chin & Ing & ER & $134-230$ \\
\hline Hirai (1999) & $\mathrm{N}=56$, universitarios & Jap & Ing & Transversal & 139 \\
\hline Iwahori (2008) & $\mathrm{N}=33,16-17$ & Jap & Ing & ER & $84-112$ \\
\hline Bell (2001) & $\begin{array}{l}\mathrm{N}=26 \text {, adultos } \\
\text { jóvenes }\end{array}$ & Arab & Ing & ER & 68 \\
\hline Lai (1993) & $\mathrm{N}=266,11-15$ & Chin & Ing & n.s & 85 \\
\hline $\begin{array}{l}\text { Rob \& Susser } \\
\text { (1989) }\end{array}$ & $\begin{array}{l}\mathrm{N}=125 \\
\text { universitarios }\end{array}$ & Jap & Ing & ER \& Skills & $\begin{array}{l}\text { Skills: } 78 \\
\text { EXP: } 79\end{array}$ \\
\hline Sheu (2003) & $\mathrm{N}=98,13-14$ & Chin & Ing & ER \& CG & $59.7-85.2$ \\
\hline $\begin{array}{l}\text { Taguchi et al. } \\
(2004)\end{array}$ & $\begin{array}{l}\mathrm{N}=20, \\
\text { mayoritariamente } 18 \\
(19 \& 60)\end{array}$ & Jap & Ing & As RR\& ER & $84.84-80.88$ \\
\hline $\begin{array}{l}\text { Taguchi \& } \\
\text { Gorsuch (2002) }\end{array}$ & $\mathrm{N}=18$, universitarios & Jap & Ing & RR & 113 \\
\hline Huffman (2014) & $\begin{array}{l}N=66, \text { univ, }(19 / 20 \\
\text { yo) }\end{array}$ & Jap & Ing & ER \& IR & $\begin{array}{l}\text { ER } 110 \\
\text { IR } 103\end{array}$ \\
\hline $\begin{array}{l}\text { Beglar \& Hunt } \\
\text { (2014) }\end{array}$ & $\begin{array}{l}N=76, \text { univ }(19 / 20 \\
\text { yo) }\end{array}$ & Jap & Ing & $\begin{array}{l}\text { PLEAS } \\
\text { READ }\end{array}$ & 97 \\
\hline $\begin{array}{l}\text { Fujita \& } \\
\text { Yamashita } \\
(2014)\end{array}$ & $\begin{array}{l}\mathrm{N}=125 \text {, instituto }(15- \\
16)\end{array}$ & Jap & Ing & Transversal & 93.8 \\
\hline $\begin{array}{l}\text { Matsui \& Noro } \\
(2010)\end{array}$ & $\begin{array}{l}\mathrm{N}=122 \text {, instituto }(12- \\
15)\end{array}$ & Jap & Ing & ER\& CG & $\begin{array}{l}\text { ER } 88.57 \\
\text { CG } 89.29\end{array}$ \\
\hline $\begin{array}{l}\text { McLean \& } \\
\text { Rouault (2017) }\end{array}$ & $\begin{array}{l}\mathrm{N}=50 \text {, universitarios } \\
\text { de primer año }\end{array}$ & Jap & Ing & $\begin{array}{l}\text { ER \& } \\
\text { Grammar- } \\
\text { Translation }\end{array}$ & $\begin{array}{l}\text { ER } 99.38 \\
\text { GRAM } 97.79\end{array}$ \\
\hline $\begin{array}{l}\text { McCollum } \\
\text { (2012) }\end{array}$ & $\begin{array}{l}\mathrm{N}=112 \\
\text { universitarios }(18-22)\end{array}$ & Arab & Ing & Transversal & $127-166$ \\
\hline
\end{tabular}


Apéndice B

Textos utilizados para examinar la habilidad lectora de los participantes en su L1 y L2

Catalán

En David era un noi de vint anys que tan sols feia una setmana que treballava com a il·lustrador en una important revista gràfica. La feina l'apassionava i, encara que reconeixia que mai no l'hauria aconseguit sense la influència del seu pare -un destacat banquer de la ciutat que es deia com ell, David García-, havia decidit agafar-se a aquella oportunitat sense dubtar-ho i lluitar amb totes les forces per guanyar-se un lloc, ell tot sol, en el difícil món de la il·lustració. De moment, durant aquella primera setmana de feina, havia servit més cafès que dibuixos havien sortit de la seva ploma, àvida d'una oportunitat. Però en David no era impacient. Al contrari, tothom el considerava un noi sensat, molt segur d'ell mateix, i posseïdor d'un caràcter amable i tranquil. En David abandonà la redacció a les set de la tarda. S'aturà al quiosc de la cantonada. Es va treure tres monedes de la butxaca i va comprar un diari. Els altres dies, després de la feina, se n'anava de dret a casa, però aquell dia era divendres i en David havia quedat amb uns amics per anar al cinema.

Español

David era un chico de veinte años que solo hacía una semana que trabajaba como ilustrador en una importante revista gráfica. Era un oficio que le apasionaba y, aunque reconocía que no lo habría conseguido nunca sin la influencia de su padre -un destacado banquero de la ciudad que se llamaba como él, David García-, había decidido aferrarse a aquella oportunidad sin dudar y luchar con todas sus fuerzas para ganarse un nombre, él solo, en el difícil mundo de la ilustración. De momento, durante aquella primera semana de trabajo, había servido más cafés que dibujos había trazado su pluma, ávida de alguna oportunidad. Pero David no era impaciente. Al contrario, todo el mundo lo consideraba un muchacho sensato, seguro de sí mismo, y con un carácter amable y tranquilo. David abandonó la redacción a las siete de la tarde. Se detuvo en el quiosco de la esquina. Sacó tres monedas de su bolsillo y compró un periódico. A diario, al salir del trabajo, se iba directo a casa, pero aquel día era viernes y David había acordado ir al cine con unos amigos.

Inglés

Fred is in his bedroom. He has some homework but he's looking out of the window. It's raining and very windy. Suddenly Fred sees something in the garden! 
It's round and grey. It's a SPACESHIP! Then he sees a little ET and a robot coming down the stairs of the spaceship!

Fred opens the window. The ET talks to Fred.

ET: Hello! I'm PB3. I'm from Planet PB3. This is my robot Robin.

Fred: Hello! My name is Frederick but you can call me Fred.

PB3 sees an apple on Fred's desk. It's a red apple. He's very surprised. On Planet P3 they don't have apples and they don't have red things! On Planet P3 the only colours are black, grey, green and white.

Fred, PB3 and Robin go to the kitchen. Fred shows PB3 and Robin some other fruit. He shows them a pear and some grapes, a banana and an orange. He shows them some vegetables too. There are potatoes and beans and a bowl of peas. PB3 and Robin are very happy.

Next day PB3 and Robin go with Fred to the village to buy some fruit and vegetables. PB3 and Robin hide in a box next to a shop. Fred buys lemons and carrots and PB3 and Robin watch from their box. They are very surprised! 
Apéndice C

Resultados de la regresión con la fluidez en la L2 como variable dependiente y Curso y fluidez en la L1 como variables independientes

\begin{tabular}{|c|c|c|c|c|c|}
\hline Modelo & $\begin{array}{l}\text { Coefici } \\
\text { estanda } \\
\text { B }\end{array}$ & $\begin{array}{l}\text { no } \\
\text { do } \\
\text { Std. Error }\end{array}$ & $\begin{array}{l}\text { Coeficiente } \\
\text { estandarizado } \\
\text { Beta }\end{array}$ & $\mathbf{t}$ & Sig. \\
\hline Constante & 48,026 & 3,522 & & 13,635 & ,000 \\
\hline Curso &, 080 & ,393 &, 006 & ,204 & ,838 \\
\hline PPM_L1 & ,233 & 011 & 619 & 21,964 &, 000 \\
\hline
\end{tabular}

Resultados de la regresión para cada curso

$5^{\circ}$ Primaria

\begin{tabular}{|c|c|c|c|c|c|}
\hline Modelo & $\begin{array}{l}\text { Coefic } \\
\text { estand } \\
\text { B }\end{array}$ & $\begin{array}{l}\text { no } \\
\text { do } \\
\text { Std. Error }\end{array}$ & $\begin{array}{l}\text { Coeficiente } \\
\text { estandarizado } \\
\text { Beta }\end{array}$ & $\mathbf{t}$ & Sig. \\
\hline Constante & 37,009 & 3,390 & & 10,916 & ,000 \\
\hline PPM_L1 & ,281 &, 029 &, 743 & 9,862 &, 000 \\
\hline
\end{tabular}

$6^{\circ}$ Primaria

\begin{tabular}{|c|c|c|c|c|c|}
\hline Modelo & $\begin{array}{l}\text { Coefici } \\
\text { estanda } \\
\text { B }\end{array}$ & $\begin{array}{l}\text { no } \\
\text { do } \\
\text { Std. Error }\end{array}$ & $\begin{array}{l}\text { Coeficiente } \\
\text { estandarizado } \\
\text { Beta }\end{array}$ & $\mathbf{t}$ & Sig. \\
\hline Constante & 55,920 & 4,283 & & 13,055 & ,000 \\
\hline PPM L1 &, 165 & ,033 &, 501 & 4,986 &, 000 \\
\hline
\end{tabular}


$1^{\circ} \mathrm{ESO}$

\begin{tabular}{|c|c|c|c|c|c|}
\hline Modelo & $\begin{array}{l}\text { Coeficic } \\
\text { estanda } \\
\text { B }\end{array}$ & $\begin{array}{l}\text { no } \\
\text { do } \\
\text { Std. Error }\end{array}$ & $\begin{array}{l}\text { Coeficiente } \\
\text { estandarizado } \\
\text { Beta }\end{array}$ & $\mathbf{t}$ & Sig. \\
\hline Constante & 46,368 & 3,771 & & 12,296 & 000 \\
\hline PPM_L1 & ,264 & ,029 &, 584 & 9,229 &, 000 \\
\hline
\end{tabular}

$2^{\circ} \mathrm{ESO}$

\begin{tabular}{|c|c|c|c|c|c|}
\hline Modelo & $\begin{array}{l}\text { Coefici } \\
\text { estand } \\
\text { B }\end{array}$ & $\begin{array}{l}\text { no } \\
\text { do } \\
\text { Std. Error }\end{array}$ & $\begin{array}{l}\text { Coeficiente } \\
\text { estandarizado } \\
\text { Beta }\end{array}$ & $\mathbf{t}$ & Sig. \\
\hline Constante & 52,868 & 2,775 & & 19,054 &, 000 \\
\hline PPM_L1 & ,237 &, 022 & ,687 & 10,619 &, 000 \\
\hline
\end{tabular}

$3^{\circ} \mathrm{ESO}$

\begin{tabular}{|c|c|c|c|c|c|}
\hline Modelo & $\begin{array}{l}\text { Coefici } \\
\text { estand } \\
\text { B }\end{array}$ & $\begin{array}{l}\text { no } \\
\text { do } \\
\text { Std. Error }\end{array}$ & $\begin{array}{l}\text { Coeficiente } \\
\text { estandarizado } \\
\text { Beta }\end{array}$ & $\mathbf{t}$ & Sig. \\
\hline Constante & 53,587 & 3,088 & & 17,355 & ,000 \\
\hline PPM L1 & ,215 & ,025 & ,597 & 8,572 &, 000 \\
\hline
\end{tabular}


$4^{\circ} \mathrm{ESO}$

\begin{tabular}{|c|c|c|c|c|c|}
\hline Modelo & $\begin{array}{l}\text { Coefic } \\
\text { estand } \\
\text { B }\end{array}$ & $\begin{array}{l}\text { no } \\
\text { do } \\
\text { Std. Error }\end{array}$ & $\begin{array}{l}\text { Coeficiente } \\
\text { estandarizado } \\
\text { Beta }\end{array}$ & $\mathbf{t}$ & Sig. \\
\hline Constante & 49,991 & 2,209 & & 22,631 & ,000 \\
\hline PPM_L1 &, 178 &, 023 &, 581 & 7,876 &, 000 \\
\hline
\end{tabular}

$1^{\circ}$ Bachillerato

\begin{tabular}{|c|c|c|c|c|c|}
\hline Modelo & $\begin{array}{l}\text { Coefici } \\
\text { estand } \\
\text { B }\end{array}$ & $\begin{array}{l}\text { no } \\
\text { do } \\
\text { Std. Error }\end{array}$ & $\begin{array}{l}\text { Coeficiente } \\
\text { estandarizado } \\
\text { Beta }\end{array}$ & $\mathbf{t}$ & Sig. \\
\hline Constante & 56,717 & 6,683 & & 8,486 & ,000 \\
\hline PPM L1 &, 146 & 057 & ,374 & 2,553 &, 000 \\
\hline
\end{tabular}

$2^{\circ}$ Bachillerato

\begin{tabular}{|c|c|c|c|c|c|}
\hline Modelo & $\begin{array}{l}\text { Coefici } \\
\text { estanda } \\
\text { B }\end{array}$ & $\begin{array}{l}\text { no } \\
\text { do } \\
\text { Std. Error }\end{array}$ & $\begin{array}{l}\text { Coeficiente } \\
\text { estandarizado } \\
\text { Beta }\end{array}$ & $\mathbf{t}$ & Sig. \\
\hline Constante & 38,225 & 2,976 & & 12,844 & ,000 \\
\hline PPM_L1 & ,274 &, 025 & ,892 & 11,175 &, 000 \\
\hline
\end{tabular}

